\title{
Functional Analysis of Catalysts for Lower Alkane Oxidation
}

\author{
Pierre Kube ${ }^{[a]}$ Benjamin Frank, ${ }^{[a]}$ Sabine Wrabetz, ${ }^{[a]}$ Jutta Kröhnert, ${ }^{[a]}$ Michael Hävecker,,${ }^{[a, b]}$ \\ Juan Velasco-Vélez, ${ }^{[a]}$ Johannes Noack, ${ }^{[a, c]}$ Robert Schlögl, ${ }^{[a]}$ and Annette Trunschke ${ }^{\star[a]}$
}

\begin{abstract}
The catalytic performance of (i) crystalline MoVTeNb oxide that exhibits the electronic properties of a n-type semiconductor, (ii) sub-monolayer vanadium oxide supported on meso-structured silica (SBA-15) as an insulating support, and (iii) surface-functionalized carbon nanotubes that contain neither a redox active metal nor bulk oxygen, but only surface oxygen species have been compared in the oxidative dehydrogenation of ethane and propane under equal reaction conditions. The catalytic results indicate similarities in the reaction network over all three catalysts within the range of the studied reaction conditions implying that differences in selectivity are a consequence of differences in the rate constants. Higher activity and selectivity to acrylic acid over MoVTeNb oxide as compared to the other two catalysts are attributed to the higher density of potential alkane adsorption sites on M1 and the specific electronic structure of the semiconducting bulk catalyst. Microcalorimetry has been used to determine and quantify different adsorption sites revealing a low $\mathrm{V}_{\text {surface }} / \mathrm{C}_{3} \mathrm{H}_{8 \text { ads }}$ ratio of 4 on $\mathrm{M} 1$ and a much higher ratio of 150 on silica-supported vanadium oxide. On the latter catalyst less than one per cent of surface vanadium atoms adsorb propane. Barriers of propane activation increase in the order P/oCNT $\left(139 \mathrm{~kJ} \mathrm{~mol}^{-1}\right) \leq \mathrm{M} 1$ (143 kJ $\left.\mathrm{mol}^{-1}\right)<6 \mathrm{~V} / \mathrm{SBA}-15\left(162 \mathrm{~kJ} \mathrm{~mol}^{-1}\right)$, which is in agreement with trends predicted by theory.
\end{abstract}

\section{Introduction}

Oxidative dehydrogenation (ODH) is an interesting alternative to current endothermic processes, like steam cracking, fluid catalytic cracking (FCC), or catalytic dehydrogenation (DH), for the manufacture of olefins from light alkanes. ${ }^{[1]}$ However, avoiding total combustion of the alkane to carbon oxides remains the major challenge that impedes application. ${ }^{[2]}$ Vanadium oxide has been regarded as promising catalyst component either in bulk mixed oxides or in the form of highly

[a] P. Kube, Dr. B. Frank, Dr. S. Wrabetz, J. Kröhnert, Dr. M. Hävecker, Dr .J. Velasco-Vélez, Dr. J. Noack, Prof. Dr. R. Schlögl, Dr. A.

Trunschke

Department of Inorganic Chemistry

Fritz-Haber-Institut der Max-Planck-Gesellschaft

Faradayweg 4-6, 14195 Berlin (Germany)

E-mail: trunschke@fhi-berlin.mpg.de

[b] Dr. M. Hävecker

Max Planck Institute for Chemical Energy Conversion Stiftstr. 34-36, D-45470 Muelheim an der Ruhr (Germany)

[C] Dr. J. Noack, and current address of Dr. B. Frank BasCat - UniCat BASF Joint Lab

TU Berlin, Sekr. EW K 01

Hardenbergstr. 36, D-10623 Berlin (Germany)

Supporting information for this article is given via a link at the end of the document. dispersed monolayers at the surface of supports. ${ }^{[3]}$

Complex mixed MoV-based oxides composed of the bronze-like structure M1 (ICSD no. 55097) (4] $^{[4}$ have been reported to show high activity in the oxidation of propane $e^{[5]}$ and ethane. Depending on feed composition and reaction conditions the catalyst primarily produces either olefins or oxygenates. ${ }^{[5]}$ Under reaction conditions the surface of $\mathrm{M} 1$ is enriched in $\mathrm{Te}^{4+}$ and $\mathrm{V}^{5+}$ forming a thin self-supported active layer. ${ }^{[5 \mathrm{~b}, 6]}$

In contrast, vanadium oxide monolayer catalysts are active in oxidative dehydrogenation, but valuable oxygenates are formed at most in traces irrespective of the reaction conditions. Supported vanadium oxide species $\mathrm{V}_{\mathrm{x}} \mathrm{O}_{\mathrm{y}}$ exist in different degree of oligomerization including monomeric species without $\mathrm{V}-\mathrm{O}-\mathrm{V}$ bonds and oligomers with different chain length. ${ }^{[3 \mathrm{e}]}$ The effect of cluster size on reactivity is still unclear. ${ }^{[39,7]}$

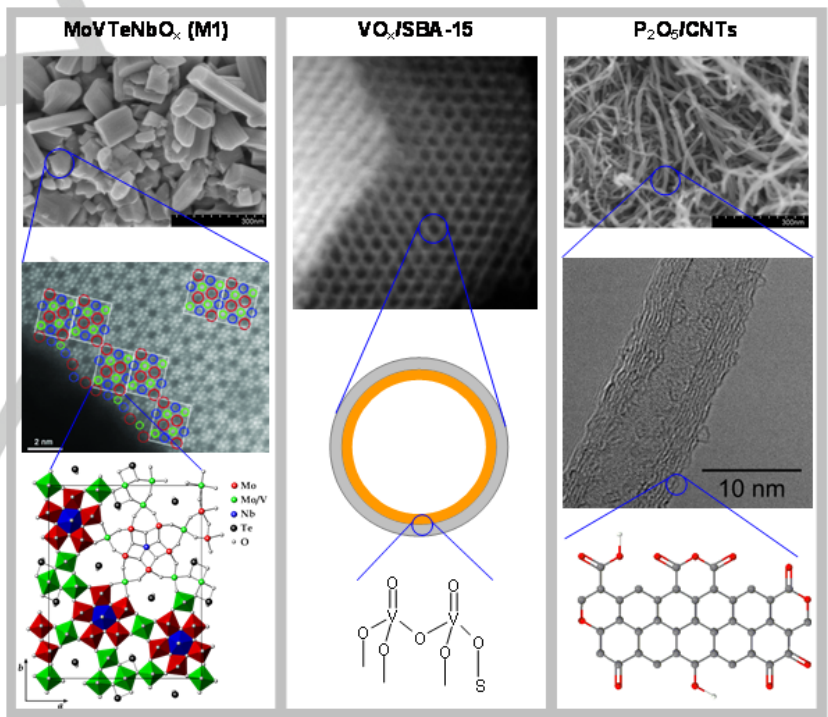

Scheme 1. Simplified illustration of potential surface features of vanadiumcontaining bulk and monolayer catalysts on the one hand and metal-free nanostructured carbon catalysts on the other hand.

Another class of catalysts is based on elemental carbon, like carbon nanotubes (CNT). ${ }^{[8]}$ Edges and defects at the carbon surface are decorated with a variety of oxygen-containing functional groups, which are structurally similar to the functional groups on vanadia catalysts (e.g., $\mathrm{V}-\mathrm{OH} / \mathrm{C}-\mathrm{OH}, \mathrm{V}=\mathrm{O} / \mathrm{C}=\mathrm{O}, \mathrm{V}$ $\mathrm{O}-\mathrm{V} / \mathrm{C}-\mathrm{O}-\mathrm{C}){ }^{\left[{ }^{[8]}\right]}$ These oxygen functionalities, in particular the redox couple of quinone and hydroquinone species, are regarded as active sites in the $\mathrm{ODH}$ reaction. ${ }^{[8 \mathrm{~b}]} \mathrm{A}$ simplified illustration of potential surface features of the three catalyst types is presented in Scheme 1.

Catalytic properties of these catalysts in oxidation of ethane 
and propane are not directly comparable due to very different reaction temperatures, contact times, and feed compositions applied so far (Tab. 1). In our work we compare bulk MoVTeNb M1 oxide with vanadium oxide supported on mesoporous silica SBA-15 and vanadium-free carbon nanotube catalysts stabilized by phosphorous oxide (referred to as M1, 6V/SBA-15, and $\mathrm{P} / \mathrm{oCNT}$, respectively) in the oxidative dehydrogenation of propane and ethane in the same temperature range and feed. The objective is to identify differences and similarities in reaction network and apparent rate parameters in order to ascertain if vanadium oxide supported on an apparently inert support, such as silica, and $V$-free carbon catalysts may serve as models for $\mathrm{V}$-containing bulk catalysts in oxidative dehydrogenation reactions of alkanes.

Table 1. Reaction conditions and catalytic properties reported in the literature for the three types of catalysts in oxidative dehydrogenation of ethane and propane.

\begin{tabular}{|c|c|c|c|c|c|c|c|c|}
\hline & & $\begin{array}{l}\mathrm{T} \\
{\left[{ }^{\circ} \mathrm{C}\right]}\end{array}$ & $\begin{array}{l}\text { Feed } \\
\text { [alkane/O } \mathrm{O}_{2} / \text { inert] }\end{array}$ & $\begin{array}{l}\mathrm{T} \\
{\left[\mathrm{g} \mathrm{s} \mathrm{ml}{ }^{-1}\right]}\end{array}$ & $\begin{array}{l}r_{\text {alkane }} \\
{\left[\mathrm{mmol} \mathrm{g}^{-1} \mathrm{~h}^{-1}\right]}\end{array}$ & $\begin{array}{l}\text { Salkene } \\
{[\%]}\end{array}$ & $\begin{array}{l}\text { Soxygenates } \\
{[\%]}\end{array}$ & Ref. \\
\hline \multicolumn{9}{|c|}{ Oxidative dehydrogenation of ethane } \\
\hline \multicolumn{9}{|l|}{ M1 } \\
\hline & $\mathrm{MoVTeNbO}_{x}^{[a]}$ & 380 & $30 / 20 / 50$ & 1.8 & 14.2 & $\sim 90$ & $\sim 10$ & [9] \\
\hline \multicolumn{9}{|l|}{$\mathrm{VO}_{x} / \mathrm{SiO}_{2}$} \\
\hline & $6.7 \mathrm{wt} \%$ V/Aerosil & 480 & 7.3/0.93/91.77 & 0.12 & 0.39 & $\sim 100$ & & [10] \\
\hline & $7.1 \mathrm{wt} \%$ V/MCM-41 & 600 & $4 / 8 / 88$ & 0.51 & 45.3 & 60.2 & 39.8 & [11] \\
\hline \multicolumn{9}{|l|}{ P/oCNT } \\
\hline & & 400 & $20 / 10 / 70$ & 0.33 & 0.24 & $\sim 66.4$ & $\sim 33.6$ & [12] \\
\hline \multicolumn{9}{|c|}{ Oxidative dehydrogenation of propane } \\
\hline \multicolumn{9}{|l|}{ M1 } \\
\hline & MoVTeNbO $_{x}$ & 380 & $8 / 10 / 37 / 45^{[\mathrm{b}]}$ & 1.5 & 107 & 8.7 & 91.3 & {$[3 i]$} \\
\hline & $\mathrm{MoVTeNbO}_{x}$ & 380 & $3 / 6 / 91$ & 0.06 & 1.7 & 89 & 11 & [13] \\
\hline \multicolumn{9}{|l|}{$\mathrm{VO}_{x} / \mathrm{SiO}_{2}$} \\
\hline & 4.5 wt $\%$ V/SBA-15 & 600 & $1 / 1 / 4$ & $2.15^{[c]}$ & $75^{[\mathrm{d}]}$ & 52 & 48 & [14] \\
\hline & $2.7 \mathrm{wt} \%$ V/SBA-15 & 500 & $16.9 / 16.9 / 67.5$ & 0.125 & 21.6 & $\sim 50$ & $\sim 50$ & [15] \\
\hline & $2.8 w t \%$ V/MCM-41 & 500 & $30 / 20 / 50$ & 0.04 & 412 & 42.3 & 41.4 & [16] \\
\hline & $7.1 \mathrm{wt} \% \mathrm{~V} / \mathrm{MCM}-41$ & 550 & $4 / 8 / 88$ & 0.8 & 33 & 45.5 & 54.5 & [11] \\
\hline & $0.5 \mathrm{wt} \% \mathrm{~V} / \mathrm{MCM}-48$ & 550 & $4 / 8 / 88$ & 11.2 & 1.13 & 65.3 & 34.7 & [17] \\
\hline & 0.5 wt $\%$ V/Aerosil & 550 & $4 / 8 / 88$ & 9.6 & 1.73 & 60.2 & 39.8 & [17] \\
\hline \multicolumn{9}{|l|}{ PloCNT } \\
\hline & & 400 & $1 / 1 / 4$ & 3 & 0.32 & 55 & 45 & [18] \\
\hline
\end{tabular}

[a] as synthesized catalyst without high-temperature treatment; [b] alkane/ $\mathrm{O}_{2} /$ inert $/ \mathrm{H}_{2} \mathrm{O}[\mathrm{c}] \mathrm{T}=\mathrm{s}[\mathrm{d}] \mathrm{r}_{\text {alkane }}\left[\mathrm{mmol} \mathrm{ml}^{-1}\right.$ cat $\left.\mathrm{h}^{-1}\right]$

\section{Results}

\section{Structure and chemical properties of the catalysts}

High crystallinity and phase-purity of the studied bulk MoVTeNb M1 oxide catalyst (M1 structure: ICSD No. 55097) have been confirmed by electron microscopy (Fig. S1) and X-ray diffraction (Fig. S2). Structural parameters of the applied M1 catalyst are summarized in the Experimental Section. The material is composed of dense, rod-like particles (Fig. S1) yielding a polycrystalline, macroporous solid that is characterized by a comparatively low specific surface area (Tab. 2, Tab. S1, Fig. S3). The macropores are formed by voids enclosed within aggregates and agglomerates of the primary catalyst particles. The total vanadium content of $\mathrm{M} 1$ is only slightly higher compared to 6V/SBA-15 (Tab. 2). The M1 surface concentration of $\mathrm{V}$ corresponds to $1.7 \mathrm{~V}$ atoms $/ \mathrm{nm}^{2}$ (Tab. 2), calculated based on XPS measurements (Fig. S4).

6V/SBA-15 features a sub-monolayer of two-dimensional vanadium oxide species on the surface of mesoporous silica SBA-15 as support. The regular pore structure of SBA-15 is essentially maintained after deposition of vanadia (Fig. S3), but the support (Tab. S1) loses roughly half of its specific surface area (Tab. 2, Tab. S1), which is mainly due to blockage of micropores by vanadium oxide species (Tab. S1). Ninety percent of the micropores are not accessible anymore for nitrogen adsorption after $\mathrm{V}$ deposition. Therefore, it is uncertain whether all the supported vanadium oxide species are accessible by molecules reacting from the gas phase. Therefore, the surface density of $1.9 \mathrm{~V}$ atoms $/ \mathrm{nm}^{2}$ (Tab. 2) calculated based on the $\mathrm{V}$ content is rather an apparent value even though 
Raman spectroscopy (Fig. S5) confirms high vanadium oxide dispersion under reaction conditions.

The nanostructured carbon catalyst is a composite of agglomerates of closely packed multi-wall carbon nanotubes (MWCNTs) (Fig. S6). The catalyst possesses a comparatively small quantity of meso- and micropores (Fig. S3, Tab. S1). This indicates that stabilization of the CNTs with phosphoric acid leads to loss of microporosity. The Raman spectrum of P/oCNTs (Fig. S7) shows bands at 1330,1590 and $1610 \mathrm{~cm}^{-1}$, denoted by D1, G, and D2 bands, respectively, in the literature, ${ }^{[19]}$ indicating defective/amorphous (D1, D2) as well as crystalline/graphitic (G) carbon domains. In addition to carbon, the catalyst contains 4.9 wt $\%$ oxygen and $1.2 \mathrm{wt} \%$ phosphorus, which was introduced via impregnation using ammonium hydrogen phosphate in order to increase the thermal stability and resistance against oxidation. ${ }^{[20]}$ The density of surface oxygen less the amount associated with phosphorous is $2.8 \mathrm{O}$ atoms $/ \mathrm{nm}^{2}$, calculated based on XPS measurement (Fig. S8).

Table 2. Specific surface area of the catalysts, concentration of the presumed active catalyst component $\mathrm{VO}_{\mathrm{x}}$ or $\mathrm{O}$, respectively, reaction rates and kinetic parameters in the oxidative dehydrogenation of propane and ethane.

\begin{tabular}{|c|c|c|c|c|}
\hline & & M1 & $6 \mathrm{~V} / \mathrm{SBA}-15$ & P/oCNT \\
\hline \multicolumn{2}{|c|}{$\mathrm{S}_{\mathrm{BET}}\left(\mathrm{m}^{2} \mathrm{~g}^{-1}\right)$} & 10.6 & 355 & 229 \\
\hline \multicolumn{2}{|c|}{ Total content of $\mathrm{V}(\mathrm{M} 1$ and $6 \mathrm{~V} / \mathrm{SBA}-15)$ and $\mathrm{O}(\mathrm{P} / \mathrm{oCNT})^{\text {[a] }}(\mathrm{wt}-\%)$} & 7.2 & 5.6 & 2.5 \\
\hline \multicolumn{2}{|c|}{ Number of surface $\mathrm{V}(\mathrm{M} 1$ and $6 \mathrm{~V} / \mathrm{SBA}-15)$ and $\mathrm{O}(\mathrm{P} / \mathrm{oCNT})$ atoms ${ }^{[\mathrm{b}]}\left(\right.$ atoms $\left.\mathrm{g}^{-1}\right)$} & $1.8 \cdot 10^{19}$ & $6.7 \cdot 10^{20}$ & $6.410^{20}$ \\
\hline \multicolumn{2}{|c|}{ Surface concentration of $\mathrm{V}(\mathrm{M} 1$ and $6 \mathrm{~V} / \mathrm{SBA}-15)$ and $\mathrm{O}(\mathrm{P} / \mathrm{oCNT})^{[\mathrm{b]}]}$ atoms $\left(\mu \mathrm{mol} \mathrm{g}{ }^{-1}\right)$} & 30 & 1113 & 1063 \\
\hline \multicolumn{2}{|c|}{ Surface density of $\mathrm{V}(\mathrm{M} 1$ and $6 \mathrm{~V} / \mathrm{SBA}-15)$ and $\mathrm{O}(\mathrm{P} / \mathrm{oCNT})$ atoms ${ }^{[\mathrm{bj}]}$ (atoms $\mathrm{nm}^{-2}$ ) } & 1.7 & 1.9 & 2.8 \\
\hline \multirow{2}{*}{\multicolumn{2}{|c|}{ Density of adsorbed propane (at constant heat of adsorption) $\left(\mathrm{nm}^{-2}\right)^{\mid c\rfloor}$}} & $0.44\left(63 \mathrm{~kJ} \mathrm{~mol}^{-1}\right)$ & $0.0014\left(52 \mathrm{~kJ} \mathrm{~mol}^{-1}\right)$ & $0.013\left(36 \mathrm{~kJ} \mathrm{~mol}^{-1}\right)$ \\
\hline & & & $0.0114\left(44 \mathrm{~kJ} \mathrm{~mol}^{-1}\right)$ & \\
\hline \multicolumn{2}{|c|}{ Differential heat of adsorption of propane $\left(\mathrm{kJ} \mathrm{mol}^{-1}\right)$} & 63 & $52-44$ & 36 \\
\hline \multicolumn{2}{|c|}{ Differential heat of adsorption of ethane $\left(\mathrm{kJ} \mathrm{mol}^{-1}\right)$} & 34 & 14 & 14 \\
\hline \multirow[t]{6}{*}{ Ethane } & $r_{\text {ethane consumption }, 0}{ }^{[\mathrm{d]}]}\left(\mathrm{mmol} \mathrm{g}^{-1} \mathrm{~h}^{-1}\right)$ & $5.4 \pm 0.2$ & $0.055 \pm 0.001$ & $0.030 \pm 0.001$ \\
\hline & $r_{\text {ethane consumption }, 0}^{[\mathrm{d}]}\left(10^{-22} \mathrm{mmol} \mathrm{nm}^{-2} \mathrm{~h}^{-1}\right)$ & 5094 & 1.5 & 1.3 \\
\hline & $r_{\text {ethylene formation, } 0}^{[\mathrm{d}]}\left(\mathrm{mmol} \mathrm{g}^{-1} \mathrm{~h}^{-1}\right)$ & $5.2 \pm 0.2$ & $0.043 \pm 0.001$ & $0.022 \pm 0.001$ \\
\hline & $E_{\mathrm{a}, \text { ethane consumption, }} 0^{[\mathrm{e}]}\left(\mathrm{kJ} \mathrm{mol}^{-1}\right)$ & $90 \pm 2$ & $121 \pm 2$ & $110 \pm 7$ \\
\hline & $n^{[\dagger]}\left(\mathrm{O}_{2}\right)$ & $0.1 \pm 0.01$ & $0.2 \pm 0.01$ & $0.4 \pm 0.02$ \\
\hline & $n^{[9]}\left(\mathrm{C}_{2} \mathrm{H}_{6}\right)$ & $0.9 \pm 0.01$ & $0.8 \pm 0.02$ & $0.6 \pm 0.01$ \\
\hline \multirow[t]{7}{*}{ Propane } & 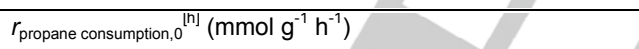 & $5.3 \pm 0.2$ & $0.45 \pm 0.006$ & $0.21 \pm 0.004$ \\
\hline & $r_{\text {propane consumption, } 0} 0^{[\mathrm{h}]}\left(10^{-22} \mathrm{mmol} \mathrm{nm}^{-2} \mathrm{~h}^{-1}\right)$ & 5000 & 12.7 & 9.2 \\
\hline & $r_{\text {propylene formation }, 0}^{[\mathrm{n}]}\left(\mathrm{mmol} \mathrm{g}^{-1} \mathrm{~h}^{-1}\right)$ & $5.1 \pm 0.04$ & $0.36 \pm 0.002$ & $0.19 \pm 0.01$ \\
\hline & $r_{\text {propylene formation }, 0}^{[\mathrm{ln}]}\left(10^{-22} \mathrm{mmol} \mathrm{nm}^{-2} \mathrm{~h}^{-1}\right)$ & 4811 & 10.1 & 8.3 \\
\hline & $E_{\mathrm{a}, \text { propane consumption, } 0}^{[\mathrm{e}]}\left(\mathrm{kJ} \mathrm{mol}^{-1}\right)$ & $80 \pm 3$ & $110 \pm 2$ & $103 \pm 7$ \\
\hline & $n^{[\dagger]}\left(\mathrm{O}_{2}\right)$ & $0.1 \pm 0.01$ & $0.3 \pm 0.01$ & $0.4 \pm 0.01$ \\
\hline & $n^{[9]}\left(\mathrm{C}_{3} \mathrm{H}_{8}\right)$ & $0.8 \pm 0.02$ & $0.8 \pm 0.02$ & $0.7 \pm 0.01$ \\
\hline
\end{tabular}

[a] $\mathrm{V}$ in case of $\mathrm{M} 1$ and $6 \mathrm{~V} / \mathrm{SBA}-15$ as determined by XRF,O in case of P/oCNT as determined by EDX (less oxygen associated with phosphate); [b] Surface analysis of M1 and P/oCNT was performed by XPS (less oxygen associated with phosphate) (Figs. S4, S8), 6V/SBA-15 contains highly dispersed vanadium oxide (Fig. S5), therefore, it was assumed that all V determined by XRF corresponds to surface V; [c] determined by propane adsorption using microcalorimetry; [d] $\mathrm{T}=380^{\circ} \mathrm{C}, \mathrm{W} / \mathrm{F}=0.06$ to $0.37 \mathrm{~g} \mathrm{~s} \mathrm{ml}^{-1}$ for $\mathrm{M} 1,1.33$ to $2.40 \mathrm{~g} \mathrm{~s} \mathrm{ml}^{-1}$ for $6 \mathrm{~V} / \mathrm{SBA}-15$ and P/oCNT; [e] T=380 $-420^{\circ} \mathrm{C}$ for M1 and $6 \mathrm{~V} / \mathrm{SBA}-15$ and $360-380^{\circ} \mathrm{C}$ for P/oCNT, feed of $\mathrm{C}_{n} \mathrm{H}_{2 n+2} / \mathrm{O}_{2} / \mathrm{N}_{2}=10 / 5 /$ balance [f] $\mathrm{T}=400^{\circ} \mathrm{C}$ for M1 and $6 \mathrm{~V} / \mathrm{SBA}-15$ and $360^{\circ} \mathrm{C}$ for P/oCNT, feed of $\mathrm{C}_{n} \mathrm{H}_{2 n+2} / \mathrm{O}_{2} / \mathrm{N}_{2}=10 / 3$ to $7 /$ balance; [g] T=400 ${ }^{\circ} \mathrm{C}$ for $\mathrm{M} 1$ and $6 \mathrm{~V} / \mathrm{SBA}-15$ and $360^{\circ} \mathrm{C}$ for P/oCNT, feed of $\mathrm{C}_{\mathrm{n}} \mathrm{H}_{2 \mathrm{n}+2} / \mathrm{O}_{2} / \mathrm{N}_{2}=6$ to $14 / 5 /$ balance; [h] T=380 ${ }^{\circ} \mathrm{C}, \mathrm{W} / \mathrm{F}=0.06$ to $0.09 \mathrm{~g} \mathrm{~s} \mathrm{ml}{ }^{-1}$ for $\mathrm{M} 1,1.34$ to $2.00 \mathrm{~g} \mathrm{~s} \mathrm{ml}^{-1}$ for 6V/SBA-15 and P/oCNT.

\section{Oxidative dehydrogenation of ethane and propane}

Oxidative dehydrogenation has been performed in the same feed and temperature range over all three catalysts, but at different contact times to compensate differences in the activity. Low conversion was adjusted to avoid consecutive reactions that prevail at higher conversion. The selectivity towards the alkene in $\mathrm{ODH}$ of (a) ethane and (b) propane at temperatures from 360 to $420^{\circ} \mathrm{C}$ are compared in Fig. 1 for all catalysts as a function of alkane conversion.

Pure silica SBA-15 shows measurable conversion in the studied temperature range (Fig. 1). The increasing olefin selectivity (12 - 16\% ethylene, $39-41 \%$ propylene) with increasing alkane conversion is a hint that gas-phase reactions or surface-initiated gas-phase reactions dominate over pure SBA-15. The opposing trends visible in Fig. 1 for SBA-15 and 6V/SBA-15 indicate that contributions of the free 
silica surface to the reactivity of the sub-monolayer catalyst 6V/SBA-15 are negligible.

The three catalysts show significant differences in the selectivity towards ethylene (Fig. 1a), while the selectivity to propylene seems to follow a similar trend with increasing conversion for all three catalysts (Fig. 1b).

Despite its low reactivity, ethylene is further oxidized in particular over $6 \mathrm{~V} / \mathrm{SBA}-15$. The selectivity of all products as a function of conversion measured in the entire range of applied temperatures and contact times is presented in Fig. 2-4.
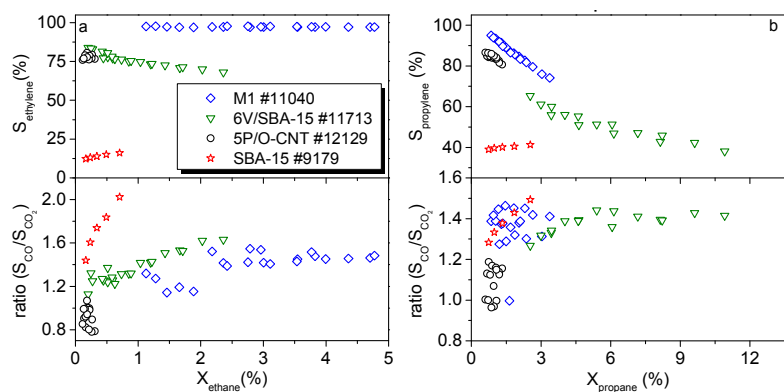

Figure 1. Selectivity as a function of alkane conversion in $\mathrm{ODH}$ of (a) ethane and (b) propane over the model catalysts at $\mathrm{T}=360-420^{\circ} \mathrm{C}, \mathrm{W} / \mathrm{F}=$ 0.034-0.72 $\mathrm{g} \mathrm{s} \mathrm{ml}^{-1}$ (M1) 1.1-2.4 $\mathrm{g} \mathrm{s} \mathrm{ml}^{-1}$ (6V/SBA-15 and P/oCNT) and 2.0 $\mathrm{g} \mathrm{s} \mathrm{ml}^{-1}$ (SBA-15) in a feed composed of $\mathrm{C}_{n} \mathrm{H}_{2 \mathrm{n}+2} / \mathrm{O}_{2} / \mathrm{N}_{2}=10 / 5 / 85$.

MoVTeNb M1 oxide shows an outstanding ethylene selectivity of $95 \%$ up to $50 \%$ conversion of ethane (Fig. 2a). Only small amounts of acetic acid are formed. Further products are $\mathrm{CO}$ and $\mathrm{CO}_{2}$, which are not formed in a common path, since the $\mathrm{S}_{\mathrm{CO}} / \mathrm{S}_{\mathrm{CO} 2}$ ratio is only constant at low conversion (Fig. 1a), but increases with increasing ethane conversion (Fig. 2a). Acrylic acid is formed as a stable oxidation product of propylene over M1 (Fig. 2b), but only traces of acids are observed over 6V/SBA-15 (Fig. 3a and b).
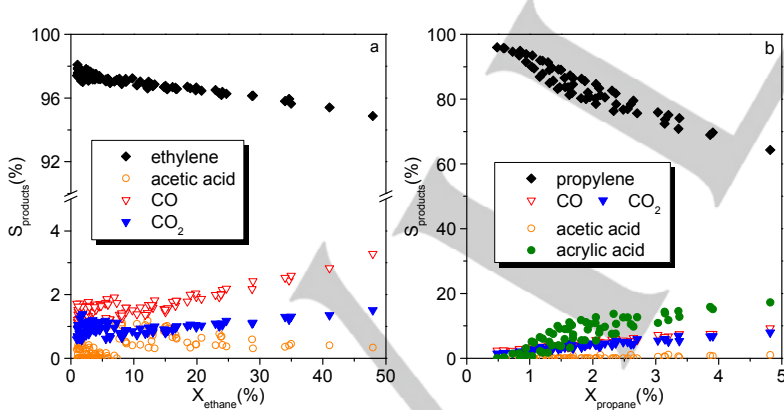

Figure 2. Selectivity of reaction products (labelled in the legend) as a function of alkane conversion in the oxidation of ethane (a) and propane (b) over MoVTeNb M1 oxide under the following reaction conditions: $\mathrm{T}=$ $350-420^{\circ} \mathrm{C}$, Feed $\mathrm{C}_{\mathrm{n}} \mathrm{H}_{2 \mathrm{n}+2} / \mathrm{O}_{2} / \mathrm{N}_{2}=10 / 5 / 85, \mathrm{~W} / \mathrm{F}=0.03-0.72 \mathrm{~g} \mathrm{~s} \mathrm{ml}^{-1}$.

Since oxygenated products have been detected at all, the low selectivity to oxygenates over 6V/SBA-15 and P/oCNTs could be rather explained by fast post-combustion of oxygen containing intermediates than by the absence of catalytic sites that accomplish oxygen insertion. Indeed, it has been shown that carbon nanotubes can catalyse the oxidation of acrolein to acrylic acid. ${ }^{[1]}$

Due to the low activity of P/oCNTs and restrictions in the reactor dimensions, the data shown in Fig. 4a have been measured at extremely low conversions between $0.1 \%$ and $0.3 \%$. In this range, the selectivity to ethylene is constant at almost $80 \%$. At such low conversions, minor contributions due to the combustion of the catalyst itself may become noticeable and may contribute to the selectivity to carbon oxides. Using a kinetic model that describes the combustion of CNTs in oxygen atmosphere, ${ }^{[20]}$ the rate of carbon combustion $r_{\mathrm{ox}}$ under the present reaction conditions (but assuming that the feed contains only $5 \% \mathrm{O}_{2}$ in $\mathrm{N}_{2}$ ) was calculated resulting in a ratio of hydrocarbon conversion $r$ to $r_{\text {ox }}$ of 2 . The impact of catalyst degeneration is certainly lower in presence of the hydrocarbon in the feed and is negligible at higher conversion as also demonstrated by the high stability of the catalyst over a term of 13-20 days on stream (Fig. S9).
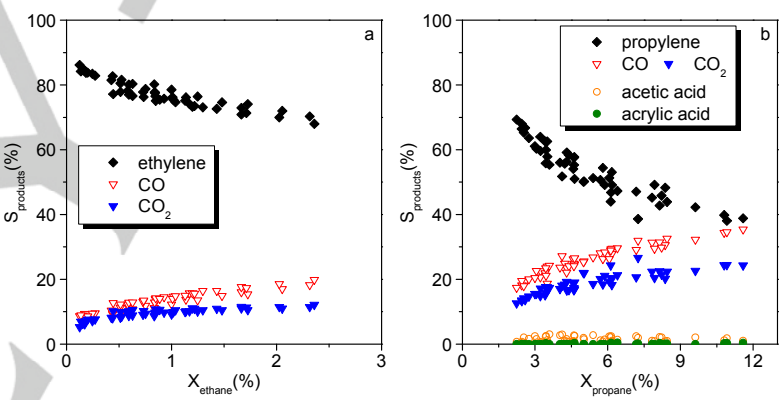

Figure 3. Selectivity of reaction products (labelled in the legend) as a function of alkane conversion in the oxidation of ethane (a) and propane (b) over 6V/SBA-15 under the following reaction conditions: $\mathrm{T}=350-$ $420^{\circ} \mathrm{C}$, Feed $\mathrm{C}_{n} \mathrm{H}_{2 n+2} / \mathrm{O}_{2} / \mathrm{N}_{2}=10 / 5 / 85, \mathrm{~W} / \mathrm{F}=0.82-2.40 \mathrm{~g} \mathrm{~s} \mathrm{ml}^{-1}$.
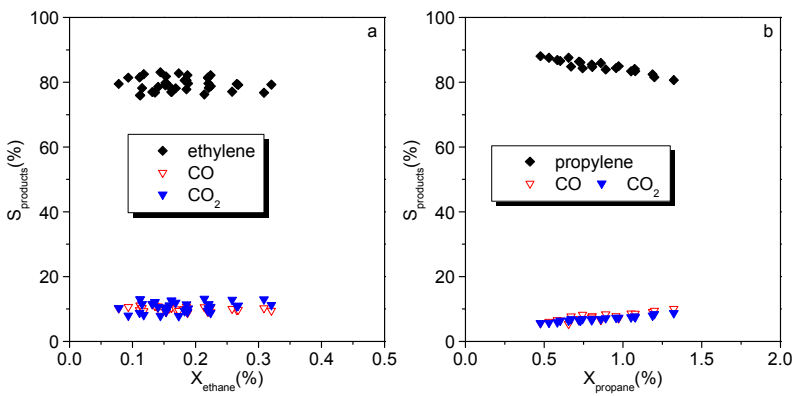

Figure 4. Selectivity of reaction products (labelled in the legend) as a function of alkane conversion in the oxidation of ethane (a) and propane (b) over P/oCNT under the following reaction conditions: $\mathrm{T}=360-480^{\circ} \mathrm{C}$ Feed $\mathrm{C}_{\mathrm{n}} \mathrm{H}_{2 \mathrm{n}+2} / \mathrm{O}_{2} / \mathrm{N}_{2}=10 / 5 / 85, W / F=0.67-2.00 \mathrm{~g} \mathrm{~s} \mathrm{ml}^{-1}$.

The consumption rate of the alkanes extrapolated to zero conversion $\left(r_{0}\right)$ at $380^{\circ} \mathrm{C}$ decreases in the order 
M1 >>6V/SBA-15>P/oCNTs (Tab. 2), irrespective of the nature of the hydrocarbon substrate. The M1 catalyst is by an order of magnitude more active in propane oxidation than sub-monolayer vanadium oxide and the transition metal-free catalyst. In case of oxidative dehydrogenation of ethane this difference comprises even two orders of magnitude. Interestingly, over M1 the rates of propane and ethane consumption, respectively, are practically the same. In contrast, ethane is more difficult to activate compared to propane over 6V/SBA-15 and P/oCNT.

The differences in activity between the three different types of catalysts can be caused by differences in the number and/or nature of active sites. Assuming that vanadium oxide species are the only active sites for $\mathrm{C}-\mathrm{H}$ activation of alkanes in both, MoVTeNb M1 oxide and 6V/SBA-15 catalysts, the vanadium species located at the surface of MoVTeNb M1 oxide are much more active compared to vanadium oxide supported on $\mathrm{SiO}_{2}$. This results from a rough estimation of the surface density of vanadium (Tab. 2). The number of surface $V$ atoms present in $1 \mathrm{~g} \mathrm{M} 1$ catalyst corresponds to approximately $1.8 \cdot 10^{19}$ atoms. The number of $V$ atoms at the surface of $1 \mathrm{~g}$ 6 V/SBA-15 is significantly higher $\left(6.7 \cdot 10^{20}\right.$ atoms $)$ and in the same order of magnitude as the surface oxygen atoms in $1 \mathrm{~g}$ P/oCNT $\left(6.4 \cdot 10^{20}\right.$ atoms). Contributions of the other elements at the surface of $\mathrm{M} 1$ cannot be excluded since, for example, supported molybdenum and niobium oxides are also active in the oxidative dehydrogenation of propane and ethane. ${ }^{[22]}$ But still, due to the low specific surface area of the MoVTeNb M1 oxide, the total number of active sites in the reactor would be smaller compared to 6V/SBA-15 even if a part of the vanadium on SBA-15 should be trapped in micropores. In summary, the apparent difference in the number of active sites suggests a significant higher intrinsic activity of the active sites at the surface of M1.

The stable catalytic performance of all three catalysts at all reaction temperatures (exemplarily shown in Fig. S9 for selected reaction temperatures in the $\mathrm{ODH}$ of propane and ethane) allowed the analysis of kinetic parameters (Figs. S10S19, Tab. 2). Apparent activation energies $\left(E_{a}\right)$ for alkane consumption were calculated based on the initial alkane consumption rates by extrapolating to zero conversion (Tab. 2). Mass transport limitations as reason for differences in the activation energy between the three catalysts can be excluded (Fig. S10). The low apparent activation energy measured over $\mathrm{M} 1$ is in agreement with its high intrinsic activity (Tab. 2). 6V/SBA-15 shows the strongest temperature dependence, followed by P/oCNT. The apparent activation energy calculated from the alkane consumption rate is higher for ethane compared to propane. Interestingly, the difference with reference to all three catalysts is nearly the same (approximately $10 \mathrm{~kJ} \mathrm{~mol}^{-1}$ (Tab. 2)).

The apparent reaction order with respect to the alkane is slightly different over the three catalysts (Tab. 2) indicating different mechanisms of $\mathrm{C}-\mathrm{H}$ bond activation in the hydrocarbon molecule over the transition metal free catalyst P/oCNT compared to the V-containing catalysts, which is in line with the results of model calculations applying density- functional theory. ${ }^{[23]}$ The oxidative dehydrogenation of methane, ethane and propane was studied over twodimensional graphene-like cluster models terminated with oxygen atoms in different configurations. The calculations reveal that the barrier for the abstraction of the first hydrogen atom $\left(59-104 \mathrm{kJmol}^{-1}\right)$ by ketone groups located at the zigzag edge of the two-dimensional graphene model is generally lower than the barrier for the abstraction of the second $\mathrm{H}$ atom $\left(82-106 \mathrm{kJmol}^{-1}\right)$ suggesting that the latter step is ratelimiting.

Oxygen activation seems to be fast over M1 under the applied reaction conditions as reflected in the low reaction order with respect to $\mathrm{O}_{2}$, but more demanding over the vanadia monolayer catalyst and, in particular, over P/oCNT (Tab. 2). Fast oxygen activation over M1 is in agreement with the experimental observations that molecular $\mathrm{O}_{2}$ can be activated at low reaction temperature for oxidation reactions in the liquid phase, ${ }^{[24]}$ and with the absence of electrophilic oxygen species as intermediates of oxygen reduction under conditions of propane oxidation. ${ }^{[5 b, 25]}$

In summary, the main differences observed in oxidative dehydrogenation over the three different types of catalysts are

(1) an order of magnitude higher intrinsic activity of M1 compared to 6V/SBA-15 and P/oCNT,

(2) acids are formed over M1, but occur only in traces over 6V/SBA-15 and P/OCNT,

(3) Facilitated oxygen activation over M1 compared to 6V/SBA-15 and P/OCNT.

The oxidative dehydrogenation of ethane and propane over vanadium oxide-based catalysts has been frequently analyzed in kinetic investigations implementing for example Eley-Rideal, ${ }^{[26]}$ Langmuir-Hinshelwood, ${ }^{[27]}$ and Mars-van Krevelen ${ }^{[22 a]}$ formalisms. In the present work, the experimental data of propane oxidation have been fitted applying a simple model-free time-law (Eq. 1) based on reaction networks presented in Scheme 2 assuming irreversibility, first order with respect to the hydrocarbon, and zero order with respect to oxygen.

$r=k \cdot\left(\frac{p_{\mathrm{C}_{3} \mathrm{H}_{8}}}{p_{0}}\right)^{m} \cdot\left(\frac{p_{\mathrm{O}_{2}}}{p_{0}}\right)^{n}$

Equation (1)

All products detected in the gas phase have been included into the simulation with the aim to identify the most relevant reaction intermediates that may be responsible for the observed selectivity patterns. Simulations were not performed for ethane oxidation due to the lower conversions and, consequently, larger errors. The fitting results are compared with the experimental data in the Supporting Information (Figs. S20-S22). The measured data points can be fitted with the same model for all three catalysts implying that the deviating selectivity patterns are a result of differences in the rate constants, but the reaction network is basically the same within the range of the studied reaction conditions. The calculated rate constants for all three catalysts are summarized in Tab. S2. For better comparison of the catalysts, the rate constants were normalized with respect to 
$k_{1}$. A graphical representation of the normalized values is presented in Fig. 5, the respective numerical values are summarized in Tab. S3.
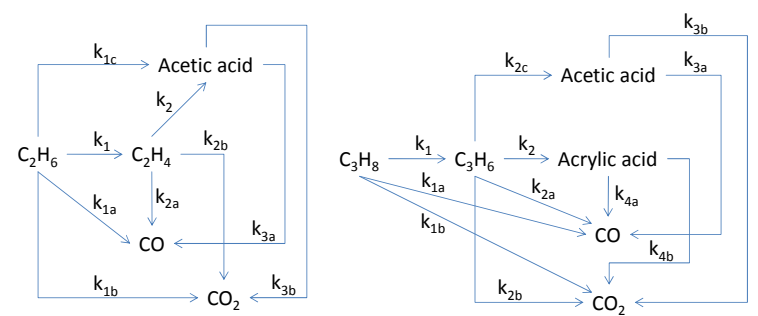

Scheme 2. Assumed reaction networks in oxidative dehydrogenation of ethane (left) and propane (right). The system of equations used for the simulation is presented in Scheme S1 for ethane, and Scheme S2 for propane, respectively, in the Supporting Information.

M1

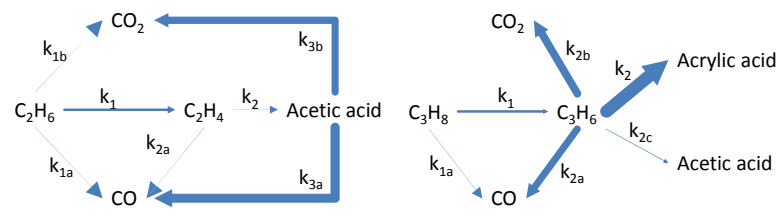

6VISBA-15

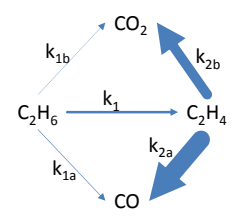

\section{PloCNT}
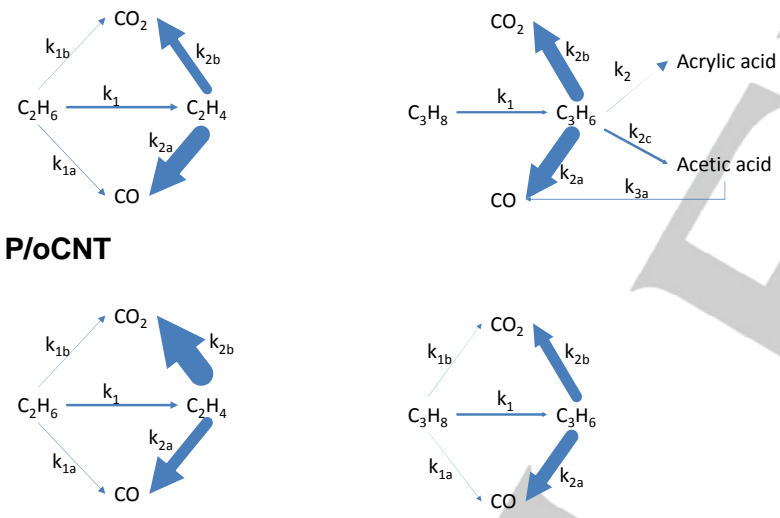

Figure 5. Graphical representation of the simulated rate constants in the oxidative dehydrogenation of ethane (left) and propane (right) over the three catalysts MoVTeNb M1 oxide, 5V/SBA-15, and P/oCNT normalized to $k_{1}$ based on the models presented in Scheme 2 .

The normalized rate constants $k_{1 a}$, and $k_{1 b}$, that represent deep oxidation of the alkane without desorption of an intermediate, as well as the rate constants $k_{2 a}$, and $k_{2 b}$, that correspond to deep oxidation of the desired olefin, are one or more orders of magnitude higher for the sub-monolayer vanadium oxide catalyst and the carbon catalyst compared to M1.

Interestingly, acetic acid formed over M1 under reaction conditions of oxidative dehydrogenation of ethane seems to be much more prone to total oxidation compared to acetic acid formed under conditions of $\mathrm{ODH}$ of propane. An increasing conductivity and a decreasing work function of MoVTeNb M1 oxide under operation in alkane oxidation have been measured by changing the organic substrate from ethane to propane to $n$-butane. ${ }^{[28]}$ This indicates progressive reduction of M1 under reaction conditions with increasing chain length of the substrate hydrocarbon. In other words, the surface of MoVTeNb M1 oxide is more oxidized in ethane containing feed compared to propane containing feed. These differences are apparently reflected in the product distribution,e.g., via consecutive reactions of the acids formed. The olefin, especially propylene, is quite selectively converted into acrylic acid by oxygen insertion over M1, while over 6V/SBA-15 and P/oCNT consecutive combustion of propylene contributes significantly to the product distribution. Based on rate constants resulting from our simulation (Scheme 2 right, Scheme S2, rate constants summarized exemplarily for one reaction temperature in Tab. S2), apparent activation energies of the most significant reaction steps in oxidative dehydrogenation of propane (Fig. 5) have been calculated (Tab. 3). Reaction steps that exhibit rate constants in the dimension of $10^{-2}$ or smaller (Tab. S2) have not been taken into account.

Table 3. Calculated apparent activation energies of the most significant reaction steps (Fig. 5) in oxidative dehydrogenation of propane over MoVTeNb M1 oxide, and 6V/SBA-15 $\left(\mathrm{T}=380-420^{\circ} \mathrm{C}\right)$ and over P/oCNT $\left(\mathrm{T}=360-380^{\circ} \mathrm{C}\right)$.

\begin{tabular}{llll}
\hline & $\begin{array}{l}\mathrm{M} 1 \\
\left(\mathrm{~kJ} \mathrm{~mol}^{-1}\right)\end{array}$ & $\begin{array}{l}\text { 6V/SBA-15 } \\
\left(\mathrm{kJ} \mathrm{mol}^{-1}\right)\end{array}$ & $\begin{array}{l}\text { P/oCNT } \\
\left(\mathrm{kJ} \mathrm{mol}^{-1}\right)\end{array}$ \\
\hline $\mathrm{E}_{\mathrm{a}, \mathrm{k} 1}$ & 86 & 110 & 100 \\
$\mathrm{E}_{\mathrm{a}, \mathrm{k} 2}$ & 65 & - & - \\
$\mathrm{E}_{\mathrm{a}, \mathrm{k} 2 \mathrm{a}}$ & 90 & 59 & 50 \\
$\mathrm{E}_{\mathrm{a}, \mathrm{k} 2 \mathrm{~b}}$ & 70 & 58 & 47 \\
\hline
\end{tabular}

The calculated $E_{a}$ values of the first step, which is the oxidative dehydrogenation of propane to propylene $\left(E_{a, k 1}\right)$, are in good accordance with the apparent activation energies calculated based on the experimentally determined initial

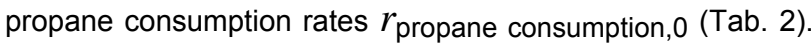
The agreement indicates that our simplified model describes the reaction network satisfactorily at least with respect to the first reaction step. Calculated activation energies of the consecutive unselective pathways of propylene to $\mathrm{CO}_{2}$ and $\mathrm{CO}, \mathrm{E}_{\mathrm{a}, \mathrm{k} 2 \mathrm{a}}$ and $\mathrm{E}_{\mathrm{a}, \mathrm{k} 2 \mathrm{~b}}$, respectively, are about $50 \mathrm{~kJ} \mathrm{~mol}^{-1}$ lower than $E_{a, k 1}$ as far as the catalysts $6 \mathrm{~V} / \mathrm{SBA}-15$ and P/oCNT are concerned. Such a difference has also been found by Chen et al. in their study of zirconia-supported vanadia catalysts in oxidative dehydrogenation of propane. ${ }^{[22 a]}$ In contrast, deep oxidation pathways of propylene to carbon oxides have higher ( $\mathrm{CO}$ formation) or only slightly lower $\left(\mathrm{CO}_{2}\right.$ formation) apparent activation energies relative to $E_{a, k 1}$ over $M 1$. As regards $M 1$, the calculated activation energy of the route from propylene to acrylic acid $\left(E_{a, k 2}\right)$ is lower than the $E_{a}$ of the 
deep oxidation pathways to $\mathrm{CO}$ and $\mathrm{CO}_{2}$. This implies that the energy of the highest transition state in the course of the acrylic acid formation route $k_{2}$ might be less than the energy of the highest transition states in deep oxidation routes of propylene over M1. Generally, $E_{a}$ calculated for all consecutive reactions of propylene are lower than $E_{a}$ for formation of propylene in the first reaction step, except reaction of propylene to $\mathrm{CO}$ over $\mathrm{M} 1$. The varying difference between $E_{a}$ of propane and propylene consumption reactions observed for the three catalysts reflects the differences in their selectivity patterns.

\section{Adsorption of alkanes and alkenes}

Differential heats of adsorption of the reactants ethane and propane and the reaction products ethylene and propylene measured at $40^{\circ} \mathrm{C}$ on all catalysts pretreated in the calorimeter cell in the reaction feed under steady-state conditions are shown in Figure 6.

Few sites $\left(0.3 \mu \mathrm{mol} \mathrm{g}^{-1}\right)$ at the surface of M1 pretreated in the ODH feed adsorb propane strongly, which is reflected in high heats of adsorption of $79 \mathrm{~kJ} \mathrm{~mol}^{-1}$ (Fig. 2, top right, dark blue line). These sites may be attributed to tellurium oxide surface species. ${ }^{[6]}$ Other sites $\left(7.7 \mu \mathrm{mol} \mathrm{^{-1 }}\right)$ show slightly weaker interaction with propane $\left(63 \mathrm{~kJ} \mathrm{~mol}^{-1}\right)$ and are more characteristic for adsorption at vanadium oxide. ${ }^{[6]}$ With increasing coverage the heat of adsorption decreases strictly and approaches a value of $20 \mathrm{~kJ} \mathrm{~mol}^{-1}$, which is close to the heat of condensation. Apparently, the surface of $\mathrm{M} 1$ exposed to $\mathrm{ODH}$ conditions (dry and rich in alkane) differs drastically from the surface of $\mathrm{M} 1$ that has been exposed to a more lean feed that contains $40 \%$ steam as usually applied when acrylic acid is the target product in propane oxidation. Here, propane is adsorbed with constant heat of adsorption of $40 \mathrm{~kJ} \mathrm{~mol}^{-1}$ until the monolayer is reached. ${ }^{[6]}$ The time constants of the heat signals measured in the present experiment at low coverage are slightly increased indicating $\mathrm{C}-\mathrm{H}$ activation of propane already at room temperature. The product of this interaction is not strongly adsorbed at the high-energy sites, since re-adsorption after evacuation at $40^{\circ} \mathrm{C}$ (light blue line in Fig. 2, top right) can be considered as reversible within the measurement accuracy.

Adsorption of propylene on M1 after two propane adsorption experiments shows lower heats of adsorption compared to propane, and reduced adsorption capacity. Moreover, propylene adsorption is partially irreversible. FTIR spectroscopy after 20 hours interaction of propylene with M1 performed to simulate the microcalorimetry experiment (Fig. 7, blue spectrum) confirms that adsorbed oxygenates are formed already at room temperature. All bands visible in Fig. 7 are due to adsorbed and gas-phase species, since the spectrum of the pretreated catalyst has been used as reference. The intense bands between 1900-1800, 17001600 , and $1500-1300 \mathrm{~cm}^{-1}$ originate from gas-phase propylene. The peaks due to adsorbed species are marked in Fig. 7. The band at $1556 \mathrm{~cm}^{-1}$ is attributed to the asymmetric $\mathrm{COO}$ stretching vibration of adsorbed carboxylate groups, while the peaks below $1300 \mathrm{~cm}^{-1}$ originate from various surface alcoholate species. ${ }^{[29]}$ Due to the strong interaction of propylene with $\mathrm{M} 1$, irreversible adsorbed intermediates of selective oxidation products are already formed at $40^{\circ} \mathrm{C}$ providing an explanation for partial irreversible adsorption.
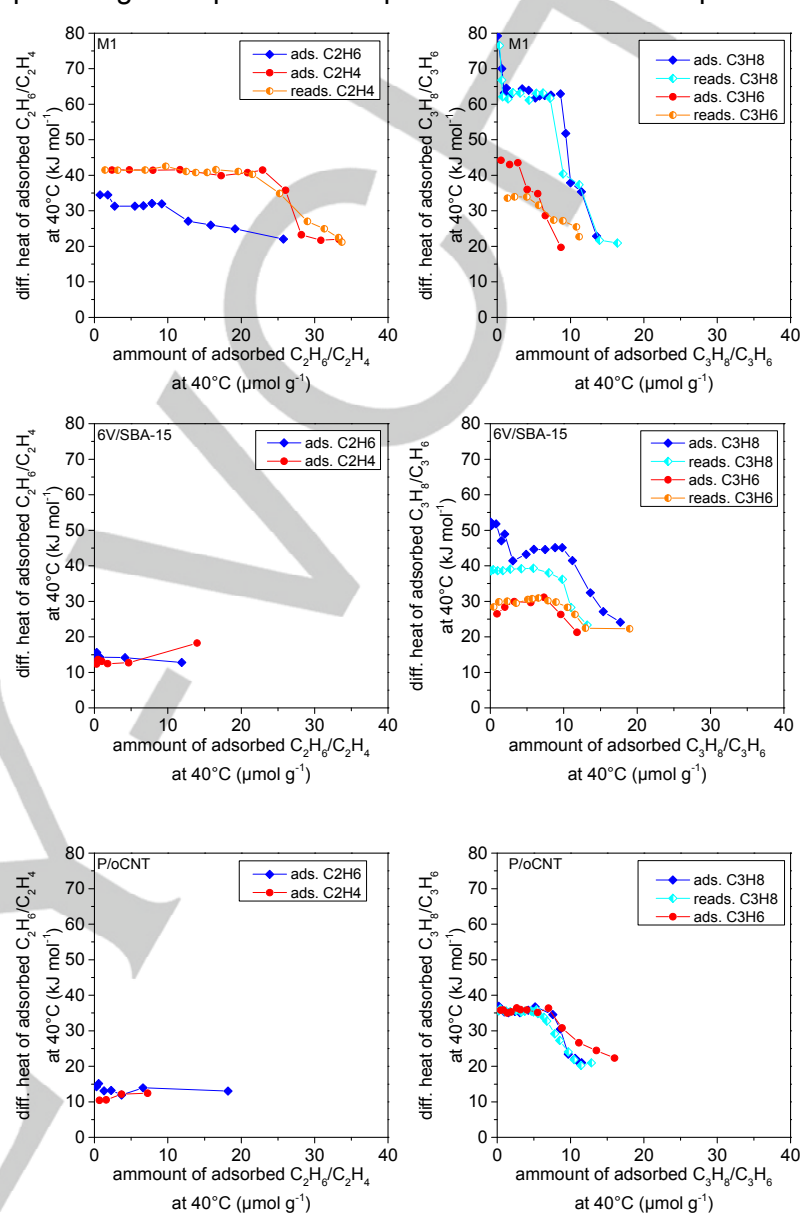

Figure 6. Differential heats of adsorption of the reactants ethane and propane and the products ethylene and propylene adsorbed at the catalysts M1, 6V/SBA-15 and P/oCNT petreated under steady-state conditions in the oxidation of propane and ethane, respectively.

Ethane shows a weaker interaction with the surface of M1 compared to propane (Fig. 6, top, left, blue line), reflected in a heat of adsorption of $34 \mathrm{~kJ} \mathrm{~mol}^{-1}\left(1.8 \mu \mathrm{mol} \mathrm{g}{ }^{-1}\right)$. With increasing coverage, weaker sites are occupied (30-20 kJ $\left.\mathrm{mol}^{-1}\right)$. Ethane adsorption is completely reversible.

Subsequent ethylene adsorption reveals that ethylene interacts stronger with $\mathrm{M} 1$ than ethane (Fig. 6, top left, red line) $\left(41 \mathrm{~kJ} \mathrm{~mol}^{-1}\right)$, but still, the adsorption is reversible (Fig. 6 top left, orange line). Due to the smaller size, adsorption capacity of $\mathrm{C} 2$ hydrocarbons on M1 is higher compared to $\mathrm{C} 3$ hydrocarbons.

At 6V/SBA-15 (Fig. 6 middle right, dark bue line), a few sites $\left(0.8 \mu \mathrm{mol} \mathrm{g} \mathrm{g}^{-1}\right)$ are characterized by a heat of propane adsorption of $52 \mathrm{~kJ} \mathrm{~mol}^{-1}$, which exhibit strong interaction with propane. At higher coverage from 0.8 to $10 \mu \mathrm{mol} \mathrm{g}^{-1}$ the heat of adsorption decreases to $44 \mathrm{~kJ} \mathrm{~mol}^{-1}$ on average. 
Adsorption of propane on 6V/SBA-15 changes the nature of the adsorption sites and also slightly the amount since readsorption of propane after evacuation at $40^{\circ} \mathrm{C}$ follows a different curve compared to the first adsorption experiment (Fig. 2, middle right, light blue line) showing a plateau at 39 $\mathrm{kJ} \mathrm{mol}^{-1}\left(8 \mu \mathrm{mol} \mathrm{\textrm {g } ^ { - 1 }}\right)$ and an overall reduced adsorption capacity. Interestingly, the amount of propane adsorbed at $6 \mathrm{~V} / \mathrm{SBA}-15$ with a heat higher than the heat of condensation is similar compared to M1 although the number of surface vanadium atoms on 6V/SBA-15 is much higher (Tab. 2).

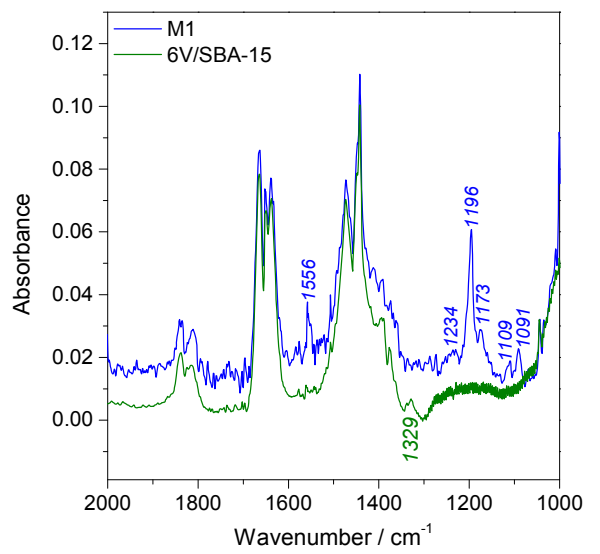

Figure 7. FTIR spectra of adsorbed species at the surface of $M 1$ and 6V/SBA-15 after adsorption of propylene at $40^{\circ} \mathrm{C}$ for 20 hours in presence of $10 \mathrm{mbar}$ propylene (equilibrium pressure). The peaks labelled with band positions arise for adsorbed species.

Propylene gives low heats of $30 \mathrm{~kJ} \mathrm{~mol}^{-1}$ at coverage of 10 $\mu \mathrm{mol} \mathrm{g}^{-1}$. The formation of carboxylate species at the surface of 6 V/SBA- 15 can be excluded due to the absence of bands in the window between 1600 and $1500 \mathrm{~cm}^{-1}$ in the infrared spectrum of propylene adsorbed on 6V/SBA-15 (Fig. 7). This suggests that the intermediate product propylene interacts differently with 6V/SBA-15 and $\mathrm{M} 1$, respectively. Unfortunately, the region below $1300 \mathrm{~cm}^{-1}$ is not accessible due to complete absorption of the infrared light by the silica support (Fig. 7) and possibly adsorbed alkoxide species cannot be probed.

Adsorption measurement of ethane and ethylene on 6V/SBA15 yield a low heat of $14 \mathrm{~kJ} \mathrm{~mol}^{-1}$, which is equal to the heat of condensation of the molecules. There is no specific interaction with the vanadium oxide species at the surface.

Propane adsorption on P/oCNT is reversible with a heat of 36 $\mathrm{kJ} \mathrm{mol}^{-1}$ and a coverage of $5 \mu \mathrm{mol} \mathrm{g}{ }^{-1}$, which corresponds to the interaction with surface functional groups. ${ }^{[30]}$ The amount of adsorbed propane is comparable with the other two catalysts.

Propylene adsorption on P/oCNT is reversible exhibiting coverages of $7 \mu \mathrm{mol}^{-1} \mathrm{~g}^{-1}$ and an adsorption heat of $36 \mathrm{~kJ}^{\cdot} \mathrm{mol}^{-1}$. Adsorption measurements of ethane and ethylene on P/oCNT yield a low heat of $14 \mathrm{~kJ} \mathrm{~mol}^{-1}$ that corresponds to the heat of condensation. There is no specific interaction with the oxygen containing functional groups at the surface.

In summary, all hydrocarbon molecules are stronger adsorbed and reach a much higher surface concentration on M1 (Tab. 2) as compared to 6V/SBA-15 and P/oCNT. Interestingly, the mean ratio of surface vanadium atoms relative to adsorbed propane molecules $\mathrm{V}_{\text {surface }} / \mathrm{C}_{3} \mathrm{H}_{8 \mathrm{ads}}(\mathrm{Tab}$. 2) corresponds to approximately 4 in case of $M 1$ and 150 in case of 6 V/SBA-15 revealing that only a part of the vanadium oxide species in 6V/SBA-15 (approximately 1\%) adsorb propane. In this respect it is interesting to note that tetramers of vanadium oxide species have been postulated to be the required ensemble size for oxidative dehydrogenation of propane. ${ }^{[2]}$ The heat of adsorption increases with the chain length of the hydrocarbon molecule on all catalysts. Propylene reacts slowly with the surface of M1 already at room temperature under formation of carboxylates. Carboxylates are not formed on the other two catalysts.

\section{Concluding Discussion}

The present study highlights three model catalysts with substantial structural diversity, which all are capable to catalyse the oxidative dehydrogenation of ethane and propane. The two $\mathrm{V}$-containing catalysts represent submonolayer catalysts. On the one hand vanadium oxide species are supported on silica as an insulating support (6V/SBA-15). On the other hand a monolayer enriched in $\mathrm{V}^{5+}$ and $\mathrm{Te}^{4+}$ is self-supported on a crystalline multi-metal mixed oxide (MoVTeNb M1 oxide) that exhibits the electronic properties of a n-type semiconductor. ${ }^{[28,31]}$ The third type of catalyst is composed of surface-functionalized carbon nanotubes (P/oCNT) that contain neither vanadium oxide nor bulk oxygen, but only surface oxygen species of which quinone-hydroquinone groups are assumed to be the active redox couple.

The catalytic performance of the three catalysts has been compared under identical reaction conditions in terms of temperature and feed composition. The results reveal general similarities such as the alkenes being the main reaction products and $\mathrm{CO}$ is preferentially formed compared to $\mathrm{CO}_{2}$ as product of deeper oxidation. However, the overall by-product spectrum and the macrokinetic parameters show the following remarkable differences:

1. The rate of alkene formation is 1-2 orders of magnitude higher over M1 compared to 6V/SBA-15 and P/oCNT.

2. Interestingly, the rate of olefin formation over M1 is approximately the same in oxidative dehydrogenation of ethane and propane. On the other two catalysts, bigger differences in the reactivity of the two alkane molecules are observed.

3. The three catalysts show different selectivity to the olefin at similar conversion. The spectrum of by-products differs as well. 


\section{Differences in activity}

We propose that the different density of alkane adsorption sites (Tab. 2) is responsible for differences in the activity of M1, 6V/SBA-15 and P/oCNT. Despite the fact that more potential $\mathrm{V}$ or oxygen adsorption sites per $\mathrm{g}$ catalyst are available at the surface of 6V/SBA-15 and P/oCNT, respectively, (Tab. 2), M1 adsorbs more alkane molecules per $\mathrm{nm}^{2}$ surface (Tab. 2, density of propane adsorption sites) and overall a similar amount per g catalyst (Fig. 6). In addition, M1 shows a higher intrinsic activity, which could be attributed to a cluster size effect (size of $\mathrm{V}_{\mathrm{x}} \mathrm{O}_{\mathrm{y}}$ oligomers) based on the low overall $\mathrm{V}_{\text {surf }} /$ propane ratio of 4 . It has been shown by DFT calculations that the barrier for abstraction of the first hydrogen atom under formation of a propyl radical decreases with increasing cluster size. ${ }^{[32]}$ Values of $160,148,139$ and $132 \mathrm{~kJ} \mathrm{~mol}^{-1}$ have been calculated for monomers, dimers, tetramers and octamers, respectively. With the assumption that all intermediates occur in pseudo-steady-state, and adsorption as well as regeneration steps are in quasiequilibrium, ${ }^{[22 \mathrm{a}]}$ the overall barrier for propylene formation can be estimated based on measured adsorption enthalpies (Fig. 6, Tab. 2) and apparent activation energies in propane oxidation (Tab. 2). The estimation is based on the assumption that the heat of adsorption is nearly independent of the temperature. ${ }^{[33]}$ The thus calculated intrinsic barrier for propane activation increases in the order P/oCNT (139 kJ $\left.\mathrm{mol}^{-1}\right)<\mathrm{M} 1\left(143 \mathrm{~kJ} \mathrm{~mol}^{-1}\right)<6 \mathrm{~V} / \mathrm{SBA}-15\left(162 \mathrm{~kJ} \mathrm{~mol}^{-1}\right)$. The similar values for $\mathrm{P} / \mathrm{OCNT}$ and $\mathrm{M} 1$ suggest similar $\mathrm{C}-\mathrm{H}$ activation mechanisms over these two catalysts. The high value for $6 \mathrm{~V} / \mathrm{SBA}-15^{[32]}$ is in agreement with the high dispersion of vanadium in 6V/SBA-15. The latter barrier has been calculated based on the heat of propane adsorption of $52 \mathrm{~kJ} \mathrm{~mol}^{-1}$ (Fig. 6, Tab. 2) that correspond to a density of adsorption sites of $0.0014 \mathrm{~nm}^{-2}$ on 6V/SBA-15 (Tab. 2). According to the DFT calculations by Rozanska et al., ${ }^{[32 a]}$ these sites could be monomeric species that comprise approximately $0.1 \%$ of all $\mathrm{V}$ atoms. At higher coverage propane adsorbs with a higher density of $0.0114 \mathrm{~nm}^{-2}$ on a different type of sites with a heat of adsorption of $44 \mathrm{~kJ} \mathrm{~mol}^{-1}$. For these sites a slightly lower barrier of $154 \mathrm{~kJ} \mathrm{~mol}^{-1}$ can be estimated, which is close to the value calculated for silicasupported vanadium oxide dimers $\left(0.6 \%\right.$ of all $V$ atoms). ${ }^{[32 a]}$ Hence, microcalorimetry apparently allows the determination and quantification of propane adsorption sites in vanadium oxide monolayer catalysts and resolves different degrees of $\mathrm{V}_{\mathrm{x}} \mathrm{O}_{\mathrm{y}}$ oligomerization.

Intrinsic barriers for ethane activation are $\left(124 \mathrm{~kJ} \mathrm{~mol}^{-1}\right)$ for $\mathrm{M} 1$, and $\left(135 \mathrm{~kJ} \mathrm{~mol}^{-1}\right)$ for $6 \mathrm{~V} / \mathrm{SBA}-15$, which is also in agreement with the activity difference.

\section{Differences in selectivity}

Hydrogen abstraction is the rate-determining step in ODH of alkanes. Therefore, the discussion above refers only to the differences in the activity. Selectivity, however, is determined by the relative values of the rate constants of the various consecutive and parallel reactions or differences in the reaction pathways, which are basically not known in great detail due to the complexity of the reaction network. Batiot and Hodnett analysed a number of oxidation reactions and observed a correlation between selectivity at fixed conversion and the difference between the bond dissociation enthalpy of the weakest $\mathrm{C}-\mathrm{H}$ bond in the reactant and the bond dissociation enthalpy of the weakest bond in the selective oxidation product irrespective of the type of oxide-based catalyst that has been used. ${ }^{[34]}$ The concept implies that energetic constraints limit selectivity in oxidation catalysis. It provides a rule of thumb to estimate the threshold value of selectivity that depends on the gas-phase stability of reactant and product. The selectivity to ethylene is expected to be high if the reaction stops at the formation of ethylene since the weakest $\mathrm{C}-\mathrm{H}$ bond in ethane (bond dissociation energy $D^{0}{ }_{C \text { - }}$ ${ }_{H}=419.5 \mathrm{~kJ}^{-1} \mathrm{~mol}^{-1}$ ) can be activated more readily than the weakest $\mathrm{C}-\mathrm{H}$ bond in ethylene $\left(D^{0}{ }_{\mathrm{C}-\mathrm{H}}=444 \mathrm{~kJ} \mathrm{~mol}^{-1}\right) \cdot{ }^{[34]}$ In the current work, however, a much higher selectivity to ethylene is observed over M1 compared to 6V/SBA-15. The difference that comprises up to $30 \%$ is not obvious within the concept mentioned above, in particular because M1 catalyses the consecutive oxidation of ethylene to acetic acid as well and should, therefore, show a lower selectivity to ethylene. In contrast, a smaller difference between M1 and 6V/SBA-15 is observed in the selectivity to propylene in ODH of propane $(10 \%)$ under the applied reaction conditions. The result is again not straightforward, because the product distribution of the two catalysts in propane oxidation is very different. The current work illustrates that in addition to the thermodynamic stability of a substrate or product molecule the interaction of reactant or product with the catalyst surface has an impact on the selectivity.

We observed only weak interaction between propylene and the V-containing catalysts, which is an unexpected result. Propylene adsorption on M1 yields adsorbed acrylates already at room temperature in a slow reaction. The high density of adsorption sites on M1 apparently renders possible concerted reactions, which involve oxygen insertion. Such an ensemble effect together with the balanced oxygen activation $^{[28]}$ result in improved selectivity to acrylic acid over MoVTeNb M1 oxide.

Vanadium oxide supported on an insulating support behaves electronically more like a single-site catalyst, whereas the selectivity over a semiconducting catalyst, such as $\mathrm{M} 1$, can be controlled by the redox-level of the (dynamic) surface layer that has an impact on the surface potential barrier, which again determines charge transfer between adsorbed molecules and the catalyst as will be explained in detail below. ${ }^{[35]}$ Comparable dynamic properties have not been proven so far on monolayer catalysts under reaction conditions. The presented results imply that the validity is limited of vanadium oxide monolayers supported on insulating supports to serve as a model for the surface layer of $\mathrm{V}$ containing bulk catalysts. Studies using isotope labeled reactants are underway to further elucidate the differences in the reaction mechanism. 


\section{Materials science of model catalysts}

The investigated catalysts represent three classes of materials with differing electronic properties. The presented results imply that counting the local density of specific structural elements $\left(\mathrm{V}_{\mathrm{x}} \mathrm{O}_{\mathrm{y}}\right.$ oligomers, quinone-hydroquinone couples) is a necessary but insufficient description of the material science required for generating an active and selective catalyst. The electronic properties with respect to charge carriers controlling the overall potential of the active structural elements needs also to be put into consideration. This is often done implicitly by choosing the "support" of an active structure. Figure 8 schematically indicates this by illustrating how the charge carriers of an assumed redox reaction are transported from the energy level of the hydrocarbon substrate to the energy level of oxygen. This downhill in energy provides an elementary driving force for the reaction to occur. It may thus be expected that the ease of charge carrier transport will affect the observed kinetics of the reaction. In agreement with the well-known concept of selectivity being the consequence of reactant abundance it can be expected that the ease of charge carrier transport limits selectivity. Resultant is the observation that fast reactions are not so selective and selective reactions are not so fast.

The semiconductor $\mathrm{M} 1$ with a termination layer containing $\mathrm{V}_{\mathrm{x}} \mathrm{O}_{\mathrm{y}}$ is characterized by a situation of band bending caused by formation of surface states in the feed of the reactant (Fig. $8 \mathrm{a}) .^{[22 \mathrm{~b}]}$ This allows connecting the electron donor level of the hydrocarbon with the electron acceptor level of the adsorbed oxygen sitting on the $\mathrm{V}_{\mathrm{x}} \mathrm{O}_{\mathrm{y}}$ d-states of the active clusters. In this way a self-limiting charge carrier transport situation is created. A facile execution of the elementary steps of hydrocarbon oxidation and oxygen reduction occurs through charge carriers from the catalyst and the steady state is maintained by provision of charge carriers from the reactants. In Figure $8 \mathrm{~b}$ the situation is shown for $\mathrm{V}_{\mathrm{x}} \mathrm{O}_{\mathrm{y}}$ supported on the insulator silica. Here no nearly free charge carriers exist in the material, no band bending occurs and no support of the charge carrier exchange between reactants can be expected from the bulk. Only local exchange between co-adsorbed reactants can cause catalytic reaction. This requires highly special geometric situations of $\mathrm{V}_{\mathrm{x}} \mathrm{O}_{\mathrm{y}}$ clusters that can store 4 redox equivalents and more than one hydrocarbon molecule plus an oxygen molecule in close proximity. It is conceivable that only few sites are structurally suitable and that combustion is facile due to the proximity of electrophilic oxygen occurring during partial charge exchange between hydrocarbon and molecular oxygen.

In Figure $8 \mathrm{c}$ we see the situation of the semi-metal $\mathrm{sp}^{2}$ carbon on which di-ketonic groups capable of undergoing charge carrier exchange with the $\mathrm{sp}^{2}$ carbon skeleton are the active sites. Here the lack of an energy gap in the carbon backbone allows facile charge carrier exchange. The localization of the electrons in the quinoidic groups provides the energy barrier necessary for selective operation. The very low numbered density of active sites for oxygen activation requires the movement of partially activated electrophilic oxygen as we know from combustion kinetics of carbon and hence provides the opportunity for facile combustion. This mobile active oxygen counteracts the low density of active di-ketonic sites that should be suitable for selective operation and leads to the poor performance both in respect of activity and selectivity.

a

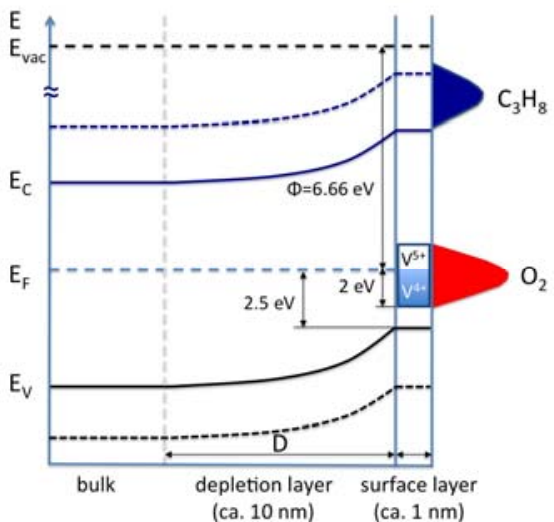

b

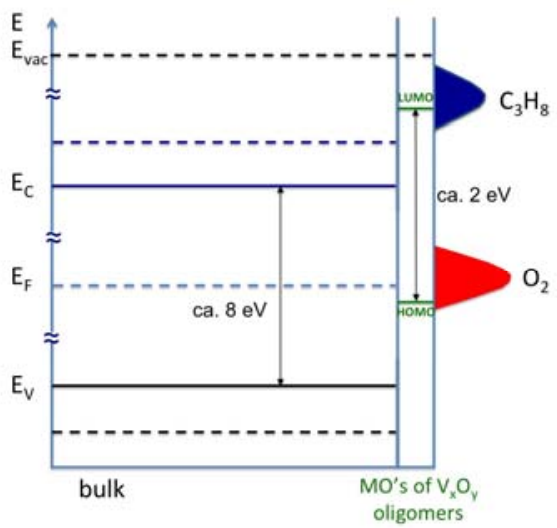

c

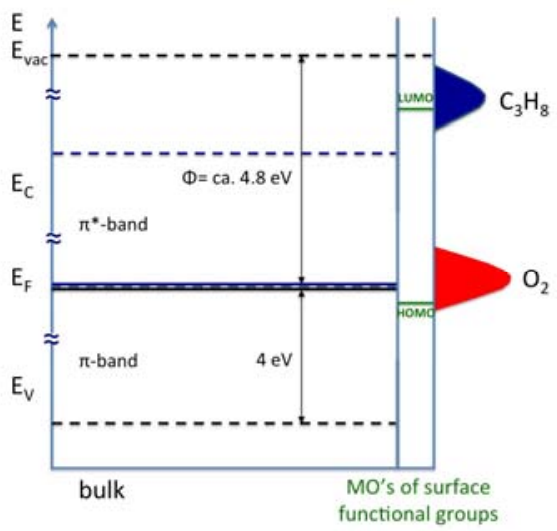

Figure 8: Schematic representation of the charge carrier transport situation in the model catalysts (a) $\mathrm{M} 1,{ }^{[22 b]}$ (b) $\mathrm{V}_{\mathrm{x}} \mathrm{O}_{\mathrm{y}} / \mathrm{SBA}-15,{ }^{[40]}$ and (c) quinone on oCNTs. 
In summary, the present study shows that fine-tuning of static and dynamical aspects of catalytic surfaces are necessary. The conventional approach focusing on a single property of a catalyst (such as the nuclearity of $\mathrm{V}_{\mathrm{x}} \mathrm{O}_{\mathrm{y}}$ clusters or their static oxidation state for example) is insufficient to capture the complexity of the dynamical situation of a redox catalyst. We note that the elementary processes of handling the protons and the formation of water being a kinetically most relevant aspect have not been considered here. This is due to the absence of macro-kinetic effects of these reactions in the chosen regime of low conversion. If catalysts are operated under higher loads these aspects become relevant and complicate the picture further as then acid-base properties are additionally relevant.

\section{Experimental Section}

\section{Catalyst preparation}

\section{Synthesis of MoVTeNb M1 oxide}

Phase-pure M1 was synthesized according to a precipitationpurification method. ${ }^{[36]}$ Briefly, $22.95 \mathrm{~g} \quad(18.57 \mathrm{mmol})$ $\left(\mathrm{NH}_{4}\right)_{6} \mathrm{Mo}_{7} \mathrm{O}_{24} \cdot 4 \mathrm{H}_{2} \mathrm{O}, 4.56 \mathrm{~g}(38.98 \mathrm{mmol}) \mathrm{NH}_{4} \mathrm{VO}_{3}$, and $6.87 \mathrm{~g}(29.91$ mmol) $\mathrm{Te}(\mathrm{OH})_{6}$ were subsequently dissolved in $100 \mathrm{ml} \mathrm{H}_{2} \mathrm{O}$ at $80{ }^{\circ} \mathrm{C}$. A solution of $7.16 \mathrm{~g}(23.63 \mathrm{mmol}) \mathrm{NH}_{4}\left[\mathrm{NbO}\left(\mathrm{C}_{2} \mathrm{O}_{4}\right)_{2}\right] \cdot \mathrm{xH}_{2} \mathrm{O}$ dissolved in $30 \mathrm{ml} \mathrm{H}_{2} \mathrm{O}$ at $40^{\circ} \mathrm{C}$ was finally added to the Mo/V/Te solution at room temperature. The obtained slurry with a nominal ratio of $\mathrm{Mo}: \mathrm{V}: \mathrm{Te}: \mathrm{Nb}=$ 1:0.3:0.23:0.18 was spray-dried. The resulting powder was calcined at $275^{\circ} \mathrm{C}$ in a flow of synthetic air $\left(100 \mathrm{ml} \mathrm{min}^{-1}\right)$ for $1 \mathrm{~h}$ and subsequently annealed at $600^{\circ} \mathrm{C}$ in a flow of $\operatorname{Ar}\left(100 \mathrm{ml} \mathrm{min}^{-1}\right)$ for $2 \mathrm{~h}$. The M2 phase present in the as-prepared biphasic MoVTeNb oxide was dissolved in a $15 \% \mathrm{H}_{2} \mathrm{O}_{2}$ solution at ambient temperature under continuous stirring for $24 \mathrm{~h}$. The washed sample was vacuum filtrated, washed with $\mathrm{H}_{2} \mathrm{O}$ and dried at $95^{\circ} \mathrm{C}$ for $3 \mathrm{~h}$. Finally, the obtained powder was treated at $600^{\circ} \mathrm{C}$ for $2 \mathrm{~h}$ in a flow of $\operatorname{Ar}\left(100 \mathrm{ml} \mathrm{min}^{-1}\right)$ resulting in crystalline, phase-pure MoVTeNb M1 oxide (sample ID 11040). The metal composition normalized to molybdenum corresponds to $\mathrm{Mo}_{1.0} \mathrm{~V}_{0.29} \mathrm{Te}_{0.1} \mathrm{Nb}_{0.15} \mathrm{O}_{x}$. Results of the basic catalyst characterization are summarized in the Supporting Information. The SEM image (Fig. S1) reveals the typical rod-shaped microstructure of the primary catalyst particles that are composed of the M1 phase only. The Rietveld refinement results of the experimental powder X-ray diffraction patterns that confirm phase purity of the catalyst are presented in Fig. S2 (lattice parameters $(\AA)$ : $a=21.1210(13)$; $b=26.5999(16) ; c=4.01689(21)$ ).

\section{Synthesis of 6VISBA-15}

Mesoporous silica SBA-15 (sample ID 9179) was used as support. The synthesis of SBA-15 has been described in detail elsewhere. ${ }^{[37]}$ Dispersed vanadia species were deposited by a grafting procedure. ${ }^{[37]}$ Briefly, $11.24 \mathrm{~g}$ support material (dried for $16 \mathrm{~h}$ at $130^{\circ} \mathrm{C}$ in air) was suspended in $284.4 \mathrm{~g}$ toluene. After $30 \mathrm{~min}, 25.58 \mathrm{~g}$ of a solution of $10.01 \mathrm{~g}(41.0 \mathrm{mmol})$ vanadium $(\mathrm{V})$ triisopropoxide in $50.23 \mathrm{~g}$ toluene was added to the SBA-15 suspension and stirred for $2 \mathrm{~h}$ at ambient temperature. The evaporation of isopropanol was performed in a rotary evaporator at $50^{\circ} \mathrm{C}$ at a residual pressure of $50 \mathrm{mbar}$. The resulting light orange powder with a nominal $\mathrm{V}$ content of $6 \mathrm{wt} \%$ was calcined at $550^{\circ} \mathrm{C}$ in static air for $2 \mathrm{~h}$. The catalyst is called 6V/SBA15 (sample ID 11713).

\section{Synthesis of P/oCNT}

Multi-walled CNTs from Nanocyl (NC3100) have been used as starting material for the synthesis of phosphorous-modified CNTs. The CNTs (sample ID 5664) were refluxed in concentrated $\mathrm{HNO}_{3}$ for $2 \mathrm{~h}$, filtrated under vacuum, washed with deionized $\mathrm{H}_{2} \mathrm{O}$ to $\mathrm{pH}$ 6-7 and dried at $110^{\circ} \mathrm{C}$ in air (oCNTs, sample ID 11450). Phosphorous modification was done by incipient wetness impregnation, using 30.66 $\mathrm{ml}$ of an aqueous $\left(\mathrm{NH}_{4}\right)_{2} \mathrm{HPO}_{4}$ solution $\left(0.247 \mathrm{~mol} \mathrm{l}^{-1} \mathrm{P}\right)$ mixed with $10.22 \mathrm{~g}$ oCNTs and $29.34 \mathrm{ml} \mathrm{H}_{2} \mathrm{O}$ to achieve a nominal loading of 5 wt $\% \mathrm{P}_{2} \mathrm{O}_{5}$. The resulting paste was thoroughly kneaded in a mortar and dried at $110^{\circ} \mathrm{C}$ for 4 days. The resulting catalyst is called P/oCNT (sample ID 12129).

\section{Catalyst characterization}

The morphology of the primary MoVTeNb M1 oxide particles was studied by scanning electron microscopy (SEM) using a Hitachi S4800 electron microscope operating at $2 \mathrm{kV}$ in secondary electron (SE) mode.

Phase analysis was performed by X-ray diffraction (XRD) using a Bruker D8 ADVANCE diffractometer ( $\mathrm{Cu}$ Ka radiation, secondary graphite monochromator, scintillation counter). The unit cell parameters of $\mathrm{M} 1$ were refined by least-square fitting of the diffraction peak positions using the M1 structure (orthorhombic, space group Pba2 [ICSD 55097]) utilizing the program package TOPAS ( $\vee 4.2$, Bruker AXS).

Nitrogen adsorption was performed at $-196^{\circ} \mathrm{C}$ using the Autosorb-6B analyser (Quantachrome) after outgassing the catalysts in vacuum (M1 for $2 \mathrm{~h}$ at $120^{\circ} \mathrm{C}, 6$ V/SBA- 15 for $16 \mathrm{~h}$ at $120^{\circ} \mathrm{C}, \mathrm{P} / \mathrm{OCNT}$ for $2 \mathrm{~h}$ at $200^{\circ} \mathrm{C}$ ). All data treatments were performed using the Quantachrome Autosorb software package. The specific surface area $S_{\mathrm{BET}}$ was calculated according to the multipoint Brunauer-Emmett-Teller method (BET) in the $p / p_{0}=0.05-0.15$ pressure range assuming the $\mathrm{N}_{2}$ cross sectional area of $16.2 \AA^{2}$. The pore size distribution of SBA-15 and 6V/SBA-15 was determined by NLDFT method using a model based on equilibrated adsorption of $\mathrm{N}_{2}$ on silica assuming cylindrical pores at $-196^{\circ} \mathrm{C}$. The micropore surface area $S_{\mu}$ was estimated using the $\mathrm{t}$-plot method in the statistical thickness $\mathrm{t}=4.5-6.5 \AA$ range. The total pore volume $V_{P}$ was determined by using the amount of physisorbed nitrogen at a relative pressure $p / p_{0}=0.95$.

X-ray fluorescence spectroscopy (XRF) was used for elemental analysis of M1 and 6V/SBA-15 applying a Bruker S4 Pioneer X-ray spectrometer. For sample preparation, the mixture of $0.1 \mathrm{~g}$ of the catalyst and $8.9 \mathrm{~g}$ of lithium tetraborate ( > $99.995 \%$, Aldrich) was fused into a disk using an automated fusion machine (Vulcan 2 MA, Fluxana).

Raman spectroscopic investigation of the catalyst samples was done at $532 \mathrm{~nm}$ excitation wavelength using a confocal TriVista microscope setup TR557 (S\&I GmbH, Warstein, Germany) equipped with a liquid nitrogen cooled spectroscopy CCD system PyLoN:2kBUV and 750 $\mathrm{mm}$ focal length of the monochromator (Princeton Instruments). Spectra resemble an average of multiple measurements at different spots of the sample. Calcination of 6V/SBA-15 and ODP reaction have been done in a CCR1000 reactor cell (Linkam Scientific, 
Tadworth, UK) at $550^{\circ} \mathrm{C}$ in synthetic air and in ODP feed $\left(\mathrm{C}_{3} \mathrm{H}_{8} / \mathrm{O}_{2} / \mathrm{N}_{2}\right.$ $=10 / 5 / 85$ ) at $380^{\circ} \mathrm{C}$, respectively.

In situ X-ray photoelectron spectroscopy (XPS) was performed at the synchrotron radiation facility BESSY II in Berlin. At the ISISS (Innovative Station for In Situ Spectroscopy) beamline monochromatic X-ray light was used to obtain high pressure XP spectra in the presence of reactive gases (alkane + oxygen) at elevated temperatures. Details of the vacuum system and the electronanalyser were reported before. ${ }^{[38]}$ For the XPS studies $10 \mathrm{mg}$ of M1 powder were pressed into a self-supporting pellet (1 ton pressing pressure, diameter of pellet: $8 \mathrm{~mm}$ ). In the experiment, $\mathrm{M} 1$ was heated to $400^{\circ} \mathrm{C}$ with a heating rate of $5 \mathrm{~K} / \mathrm{min}$ in the presence of alkane/oxygen feed (volume flow ratio $1 \mathrm{sccm} / 2 \mathrm{sccm}$ ). The total pressure was $25 \mathrm{~Pa}$ during the experiment. Alkanes, olefins (ethylene, propylene), CO, and $\mathrm{CO}_{2}$ were analyzed with a micro gas chromatograph (micro-GC, Varian) after compressing the gas to atmospheric pressure. In parallel, the oxygenates (acetic acid, acrylic acid, maleic anhydride) were detected with a proton transfer reaction mass spectrometer (PTR-MS, IONICON). Core level spectra of O1s, V2p, Mo3d, Nb3d, Te3d, and C1s were obtained with a constant kinetic electron energy of $150 \mathrm{eV}$ corresponding to an inelastic mean free path (IMFP) of $0.6 \mathrm{~nm}$. To calculate the elemental composition at the surface of $\mathrm{M} 1$, normalized core level intensities were evaluated after subtraction of a Shirley type background taking into account the photon energy dependence of the atomic subshell photoionization cross sections, ${ }^{[39]}$ using CASA data analysis software (Neil Farley, www.casaxps.com). Atomic abundance for PoCNT was performed following the same procedure and same KE (150 eV). The background was subtracted using a Shirley type. The analyzed peaks were C 1s, O1s and P 2p.

\section{Catalytic tests}

The catalytic tests were carried out using a setup for partial oxidation (Integrated Lab Solutions) with 8 fixed bed quartz reactors $(6 \mathrm{~mm}$ inner diameter) in parallel. Each reactor was equipped with a thermocouple for measuring the temperature inside the catalyst bed. The catalytic performance was determined at atmospheric pressure under steady state conditions. The reactant feed comprised the hydrocarbon $\left(\mathrm{C}_{3} \mathrm{H}_{8}\right.$ or $\left.\mathrm{C}_{2} \mathrm{H}_{6}\right), \mathrm{O}_{2}$, and $\mathrm{N}_{2}$ as diluent. The reaction conditions have been varied and are indicated in the results part. Starting and reference point for all variations was $360^{\circ} \mathrm{C}(\mathrm{P} / \mathrm{OCNT})$ or $400^{\circ} \mathrm{C}(\mathrm{M} 1,6 \mathrm{~V} / \mathrm{SBA}-15$, and SBA-15) and a dry feed of $10 \%$ hydrocarbon, $5 \% \mathrm{O}_{2}$, and $85 \% \mathrm{~N}_{2}$. The catalysts were pressed under $\sim 55 \mathrm{MPa}$, crushed and sieved to a particle size of 250-355 $\mu \mathrm{m}$. Then, different amounts of catalyst were loaded into the reactor to realise different contact times at the same gas flow. In the case of the low amount of M1 samples, the catalyst was diluted with $\sim 3 \mathrm{~g}$ of $\mathrm{SiC}$ (sieve fraction 250-355 $\mu \mathrm{m}$ ). The calculated pressure drop was below $0.5 \mathrm{mbar}$ for all loadings. A total flow of $10 \mathrm{ml} / \mathrm{min}$ was used in all experiments.

An online gas chromatograph (Agilent 7890A) is used for gas analysis. A combination of Plot-Q (length $30 \mathrm{~m}, 0.53 \mathrm{~mm}$ internal diameter, 40 $\mu \mathrm{m}$ film thickness) and Plot-MoleSieve $5 \mathrm{~A}$ columns (30 m length, 0.53 $\mathrm{mm}$ internal diameter, $50 \mu \mathrm{m}$ film thickness), connected to a thermal conductivity detector (TCD), was used to analyse the permanent gases $\mathrm{CO}, \mathrm{CO}_{2}, \mathrm{~N}_{2}, \mathrm{O}_{2}$, and $\mathrm{CH}_{4}$. A system of a FFAP (length $30 \mathrm{~m}$, $0.53 \mathrm{~mm}$ internal diameter, $1 \mu \mathrm{m}$ film thickness) and a Plot-Q column (length $30 \mathrm{~m}, 0.53 \mathrm{~mm}$ internal diameter, $40 \mu \mathrm{m}$ film thickness), connected to a flame ionization detector (FID), was used to analyse $\mathrm{C}_{2}-\mathrm{C}_{3}$ hydrocarbons and oxygenates.
Conversion of propane $X$ and product selectivity $S_{k}$ were calculated based on the sum of products as follows:

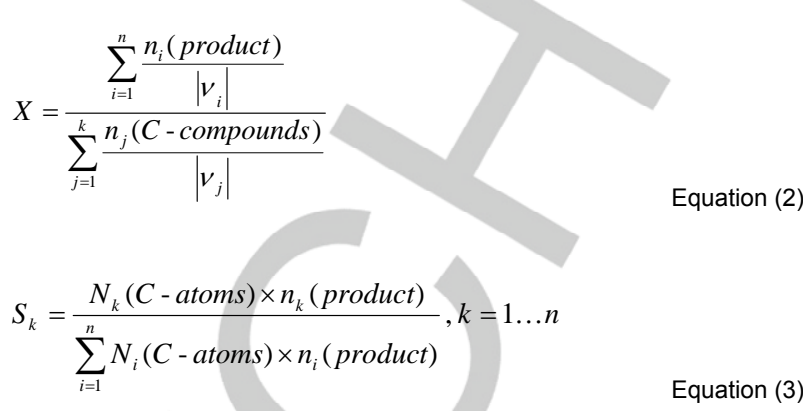

Reaction rates for propane consumption and propylene formation were determined using the following equation.

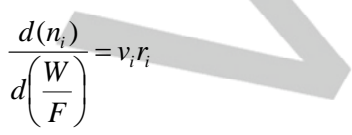

Equation (4)

Reaction rates at zero contact time are obtained by linear extrapolation of the calculated reaction rates to $\mathrm{W} / \mathrm{F}=0$.

Absence of external and internal transport limitations were verified by calculating the dimensionless Mears and Weisz-Prater criteria and measuring the catalyst performance for different catalyst amounts in two different gas flows (10 and $15 \mathrm{ml} / \mathrm{min}$ ) (see Figure $\mathrm{S10}$, data at contact time $0.06 \mathrm{~g} \mathrm{~s} \mathrm{~m}^{-1}$ ). The very active $\mathrm{M} 1$ catalyst shows the highest Mears-modulus of $3.3 \cdot 10^{-6}$ and a Weisz-Prater modulus of $1.76 \cdot 10^{-3}$ indicating that neither external nor internal mass transport limitations play a role.

\section{Microcalorimetry}

Differential heats of propane and propylene adsorption on used catalysts were determined at $313 \mathrm{~K}$ using a MS70 Calvet Calorimeter (SETRAM). The catalysts were pretreated in the calorimeter cell in a feed of $10 \%$ hydrocarbon $\left(\mathrm{C}_{3} \mathrm{H}_{8}\right.$ or $\left.\mathrm{C}_{2} \mathrm{H}_{6}\right)$ and $5 \%$ oxygen in helium with a total flow rate of $20 \mathrm{ml} \mathrm{min}^{-1}$. The reaction temperature was $400^{\circ} \mathrm{C}$ for $6 \mathrm{~V} / \mathrm{SBA}-15,360^{\circ} \mathrm{C}$ for $\mathrm{P} / \mathrm{OCNT}$ and $350^{\circ} \mathrm{C}$ for $\mathrm{M} 1$. The reaction was performed at steady state for 20 hours, subsequently, the cell was cooled down to room temperature in pure helium. The cell was then sealed and transferred to the calorimeter. The calorimeter is equipped with a custom-designed high vacuum and gas dosing apparatus. Hydrocarbons were stepwise introduced into the evacuated cell ( $p<3 \cdot 10^{-8} \mathrm{mbar}$ ), and the pressure evolution and the heat signal were recorded for each dosing step.

\section{In-situ FTIR spectroscopy}

FTIR spectra of adsorbed species at the surface were measured using a PE100 spectrometer (Perkin Elmer) equipped with a MCT detector and a homemade quartz cell, which is connected to a vacuum and gas dosing system. The spectra were recorded with 64 scans and a resolution of $4 \mathrm{~cm}^{-1}$. Catalyst powders were pressed with $260 \mathrm{MPa}$ into self-supported wafers and the samples were pre-treated as follows. In case of M1, the sample was heated up in vacuum to $400^{\circ} \mathrm{C}$ with $10 \mathrm{~K} \mathrm{~min}^{-1}$. After a hold time of $30 \mathrm{~min}$ the sample was cooled to $40^{\circ} \mathrm{C}$ and the final starting pressure for the experiment was 
Keywords: Silica-supported vanadium oxide $\cdot$ M1 phase $•$ $\mathrm{CNTs} \cdot \mathrm{C}-\mathrm{H}$ activation $\cdot$ reaction mechanism

$1.3 \cdot 10^{-6}$ mbar. 6 V/SBA-15 was heated up in 200 mbar oxygen to $550^{\circ} \mathrm{C}$ with a heating rate of $10 \mathrm{~K} \mathrm{~min}^{-1}$. After $30 \mathrm{~min}$ hold time the sample was cooled to $100^{\circ} \mathrm{C}$. At this temperature the cell was evacuated and cooled to $40^{\circ} \mathrm{C}$. Final starting pressure for the experiment was $9.1 \cdot 10^{-6} \mathrm{mbar}$. Propylene was stepwise introduced at $40^{\circ} \mathrm{C}$ up to $10 \mathrm{mbar}$ and left for $20 \mathrm{~h}$ under these conditions. Then the measurement was performed using the spectra of the pre-treated catalysts as reference.

\section{Acknowledgements}

We thank Dr. M. Sanchez-Sanchez and Dr. T. Wolfram for the synthesis of the catalysts, Dr. F. Girgsdies and E. Kitzelmann for XRD experiments, M. Hashagen and $G$. Lorenz for BET measurements, G. Weinberg for SEM measurements and Dr. C. Heine and Dr. R. Naumann d'Alnoncourt for the experimental assistance.

[1] aF. Cavani, N. Ballarini, A. Cericola, Catalysis Today 2007, 127, 113-131; bF. Cavani, Catalysis Today 2010, 157, 8-15.

[2] R. Schlögl, Topics in Catalysis 2011, 54, 627-638.

[3] aG. C. Bond, S. F. Tahir, Applied Catalysis 1991, 71, 1-31; bE. A. Mamedov, V. Cortés Corberán, Applied Catalysis A: General 1995, 127, 1-40; cT. Blasco, J. M. Lopez Nieto, Applied Catalysis, A: General 1997, 157, 117-142; dB. M. Weckhuysen, D. E. Keller, Catalysis Today 2003, 78, 25-46; eC. Hess, ChemPhysChem 2009, 10, 319-326; fN. F. Dummer, J. K. Bartley, G. J. Hutchings, in Advances in Catalysis, Vol 54, Vol. 54 (Eds.: B. C. Gates, H. Knozinger), Elsevier Academic Press Inc, San Diego, 2011, pp. 189-247; gl. E. Wachs, Dalton Transactions 2013, 42, 1176211769; hA. Trunschke, in Nanostructured Catalysts: Selective Oxidation Reactions, 1 ed. (Eds.: C. Hess, R. Schlögl), RSC Nanoscience \& Nanotechnology, Cambridge, 2011, pp. 56-95; iW. Ueda, D. Vitry, T. Katou, Catalysis Today 2005, 99, 43-49; jH. Launay, S. Loridant, D. L. Nguyen, A. M. Volodin, J. L. Dubois, J. M. M. Millet, Catalysis Today 2007, 128, 176-182; kA. Chieregato, J. M. López Nieto, F. Cavani, Coordination Chemistry Reviews 2015, 301-302, 3-23.

[4] aP. DeSanto, Jr., D. J. Buttrey, R. K. Grasselli, C. G. Lugmair, A. F. Volpe, Jr., B. H. Toby, T. Vogt, Zeitschrift fuer Kristallographie 2004, 219, 152-165; bX. Li, D. Buttrey, D. Blom, T. Vogt, Topics in Catalysis 2011, 54, 614-626.

[5] aD. Vitry, Y. Morikawa, J. L. Dubois, W. Ueda, Topics in Catalysis 2003, 23, 47-53; bR. Naumann D'Alnoncourt, L. I. Csepei, M. Hävecker, F. Girgsdies, M. E. Schuster, R. Schlögl, A. Trunschke, Journal of Catalysis 2014, 311, 369-385.

[6] M. Hävecker, S. Wrabetz, J. Kröhnert, L.-I. Csepei, R. Naumann d'Alnoncourt, Y. V. Kolen'ko, F. Girgsdies, R. Schlögl, A. Trunschke, Journal of Catalysis 2012, 285, 48-60.

[7] aP. Gruene, T. Wolfram, K. Pelzer, R. Schlögl, A. Trunschke, Catalysis Today 2010, 157, 137-142; bM. D. Argyle, K. Chen, A. T. Bell, E. Iglesia, Journal of Catalysis 2002, 208, 139-149.

[8] aJ. Zhang, X. Liu, R. Blume, A. Zhang, R. Schlögl, D. S. Su, Science 2008, 322, 73-77; bD. S. Su, J. Zhang, B. Frank, A. Thomas, X. Wang, J. Paraknowitsch, R. Schlögl, ChemSusChem 2010, 3, 169-180.
[9] T. T. Nguyen, M. Aouine, J. M. M. Millet, Catalysis Communications 2012, 21, 22-26.

[10] J. Le Bars, J. C. Vedrine, A. Auroux, S. Trautmann, M. Baerns, Applied Catalysis A: General 1992, 88, 179-195.

[11] B. Solsona, T. Blasco, J. M. Lopez Nieto, M. L. Pena, F. Rey, A Vidal-Moya, Journal of Catalysis 2001, 203, 443-452.

[12] B. Frank, M. Morassutto, R. Schomäcker, R. Schlögl, D. S. Su, ChemCatChem 2010, 2, 644-648.

[13] R. Naumann d'Alnoncourt, Y. V. Kolen'ko, R. Schlögl, A. Trunschke, Combinatorial Chemistry and High Throughput Screening 2012, 15 , 161-169.

[14] Y.-M. Liu, Y. Cao, N. Yi, W.-L. Feng, W.-L. Dai, S.-R. Yan, H.-Y. He, K.-N. Fan, Journal of Catalysis 2004, 224, 417-428.

[15] A. Dinse, S. Khennache, B. Frank, C. Hess, R. Herbert, S. Wrabetz, R. Schlögl, R. Schomäcker, Journal of Molecular Catalysis A: Chemical 2009, 307, 43-50.

[16] O. V. Buyevskaya, A. Brückner, E. V. Kondratenko, D. Wolf, M. Baerns, Catalysis Today 2001, 67, 369-378.

[17] M. L. Pena, A. Dejoz, V. Fornes, F. Rey, M. I. Vazquez, J. M. Lopez Nieto, Applied Catalysis, A: General 2001, 209, 155-164.

[18] B. Frank, J. Zhang, R. Blume, R. Schlögl, D. S. Su, Angewandte Chemie International Edition 2009, 48, 6913-6917.

[19] A. Sadezky, H. Muckenhuber, H. Grothe, R. Niessner, U. Pöschl, Carbon 2005, 43, 1731-1742.

[20] B. Frank, A. Rinaldi, R. Blume, R. Schlögl, D. S. Su, Chemistry of Materials 2010, 22, 4462-4470.

[21] B. Frank, R. Blume, A. Rinaldi, A. Trunschke, R. Schlögl, Angewandte Chemie - International Edition 2011, 50, 10226-10230.

[22] aA. Celaya Sanfiz, T. W. Hansen, D. Teschner, P. Schnörch, F. Girgsdies, A. Trunschke, R. Schlögl, M. H. Looi, S. B. A. Hamid, The Journal of Physical Chemistry C 2010, 114, 1912-1921; bC Heine, M. Hävecker, M. Sanchez-Sanchez, A. Trunschke, R. Schlögl, M. Eichelbaum, The Journal of Physical Chemistry C 2013 117, 26988-26997; cC. Heine, M. Havecker, A. Trunschke, R. Schlögl, M. Eichelbaum, Physical Chemistry Chemical Physics 2015, 17, 8983-8993.

[23] aK. Chen, A. T. Bell, E. Iglesia, The Journal of Physical Chemistry B 2000, 104, 1292-1299; bE. Heracleous, M. Machli, A. A. Lemonidou, I. A. Vasalos, Journal of Molecular Catalysis A: Chemical 2005, 232, 29-39; cP. Viparelli, P. Ciambelli, L. Lisi, G. Ruoppolo, G. Russo, J. C. Volta, Applied Catalysis A: General 1999, 184, 291-301; dC. S. Guo, K. Hermann, M. Hävecker, J. P. Thielemann, P. Kube, L. J. Gregoriades, A. Trunschke, J. Sauer, R. Schlögl, The Journal of Physical Chemistry C 2011, 115, 15449-15458; eK. Amakawa, L. Sun, C. Guo, M. Hävecker, P. Kube, I. E. Wachs, S. Lwin, A. I. Frenkel, A. Patlolla, K. Hermann, R. Schlögl, A. Trunschke, Angewandte Chemie International Edition 2013, 52, 13553-13557.

[24] O. V. Khavryuchenko, B. Frank, A. Trunschke, K. Hermann, R. Schlögl, The Journal of Physical Chemistry C 2013, 117, 6225-6234.

[25] K. Amakawa, Y. V. Kolen'ko, A. Villa, M. E. Schuster, L.-I. Csepei, G. Weinberg, S. Wrabetz, R. Naumann d'Alnoncourt, F. Girgsdies, L. Prati, R. Schlögl, A. Trunschke, ACS Catalysis 2013, 3, 1103-1113.

[26] J. Kubo, N. Watanabe, W. Ueda, Chemical Engineering Science 2008, 63, 1648-1653.

[27] R. Grabowski, J. Słoczyński, Chemical Engineering and Processing Process Intensification 2005, 44, 1082-1093.

[28] R. Quintana-Solórzano, G. Barragán-Rodríguez, H. ArmendárizHerrera, J. M. López-Nieto, J. S. Valente, Fuel 2014, 138, 15-26.

[29] aV. Sanchez Escribano, G. Busca, V. Lorenzelli, The Journal of Physical Chemistry 1990, 94, 8939-8945; bM. McEntee, W. Tang, M. Neurock, J. T. Yates, Journal of the American Chemical Society 2014, 136, 5116-5120; cP. G. Harrison, B. Maunders, Journal of the Chemical Society, Faraday Transactions 1: Physical Chemistry in Condensed Phases 1985, 81, 1345-1355; dE. Finocchio, G. Busca, V. Lorenzelli, V. S. Escribano, Journal of the Chemical Society, 
Faraday Transactions 1996, 92, 1587-1593; eP. Concepción, P. Botella, J. M. L. Nieto, Applied Catalysis A: General 2004, 278, 4556; fR. Coast, M. Pikus, P. N. Henriksen, G. A. Nitowski, The Journal of Physical Chemistry 1996, 100, 15011-15014.

[30] B. Frank, S. Wrabetz, O. V. Khavryuchenko, R. Blume, A. Trunschke, R. Schlögl, ChemPhysChem 2011, 12, 2709-2713.

[31] J.-M. M. Millet, Topics in Catalysis 2006, 38, 83-92.

[32] aX. Rozanska, R. Fortrie, J. Sauer, Journal of the American Chemical Society 2014, 136, 7751-7761; bX. Rozanska, R. Fortrie, J. Sauer, The Journal of Physical Chemistry C 2007, 111, 60416050.

[33] aD. C. Tranca, N. Hansen, J. A. Swisher, B. Smit, F. J. Keil, The Journal of Physical Chemistry C 2012, 116, 23408-23417; bE. J. Maginn, A. T. Bell, D. N. Theodorou, The Journal of Physical Chemistry 1995, 99, 2057-2079.

[34] C. Batiot, B. K. Hodnett, Applied Catalysis A: General 1996, 137, 179-191.

[35] M. Eichelbaum, M. Hävecker, C. Heine, A. M. Wernbacher, F. Rosowski, A. Trunschke, R. Schlögl, Angewandte Chemie International Edition 2015, 54, 2922-2926.

[36] Y. V. Kolen'ko, W. Zhang, R. N. d'Alnoncourt, F. Girgsdies, T. W. Hansen, T. Wolfram, R. Schlögl, A. Trunschke, ChemCatChem 2011, 3, 1597-1606.

[37] N. Hamilton, T. Wolfram, G. Tzolova Müller, M. Hävecker, J. Kröhnert, C. Carrero, R. Schomäcker, A. Trunschke, R. Schlögl, Catalysis Science \& Technology 2012, 2, 1346-1359.

[38] H. Bluhm, M. Hävecker, A. Knop-Gericke, M. Kiskinova, R. Schlögl, M. Salmeron, MRS Bulletin 2007, 32, 1022-1030.

[39] J. J. Yeh, I. Lindau, Atomic Data and Nuclear Data Tables 1985, 32, 1-155.

[40] D. Maganas, A. Trunschke, R. Schlögl, F. Neese, Faraday Discussions, 2016, 188, 181-197. 


\section{Entry for the Table of Contents}

Layout 1:

\section{FULL PAPER}

Molecular aspects in terms oft the number of adsorption sites determined by microcalorimetry, and collective electronic properties of the bulk are integrated in a concept that explains differences in the performance of single-site and bulk catalysts for oxidation of ethane and propane.

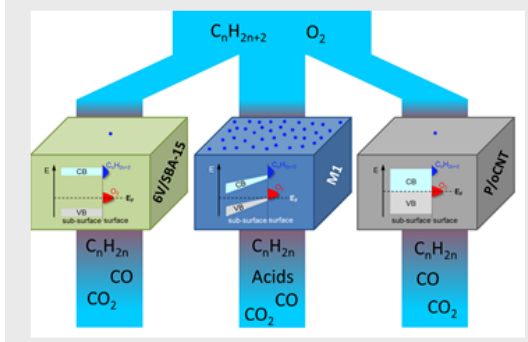

Pierre Kube, Benjamin Frank, Sabine Wrabetz, Jutta Kröhnert, Michael Hävecker, Juan Velasco-Vélez, Johannes Noack, Robert Schlögl, and Annette Trunschke*

Page No. - Page No.

Functional Analysis of Catalysts for Lower Alkane Oxidation 